Prepared in cooperation with the City of Summerset

\title{
Hydrogeology and Groundwater Flow in Alluvial Deposits, North Summerset, South Dakota
}

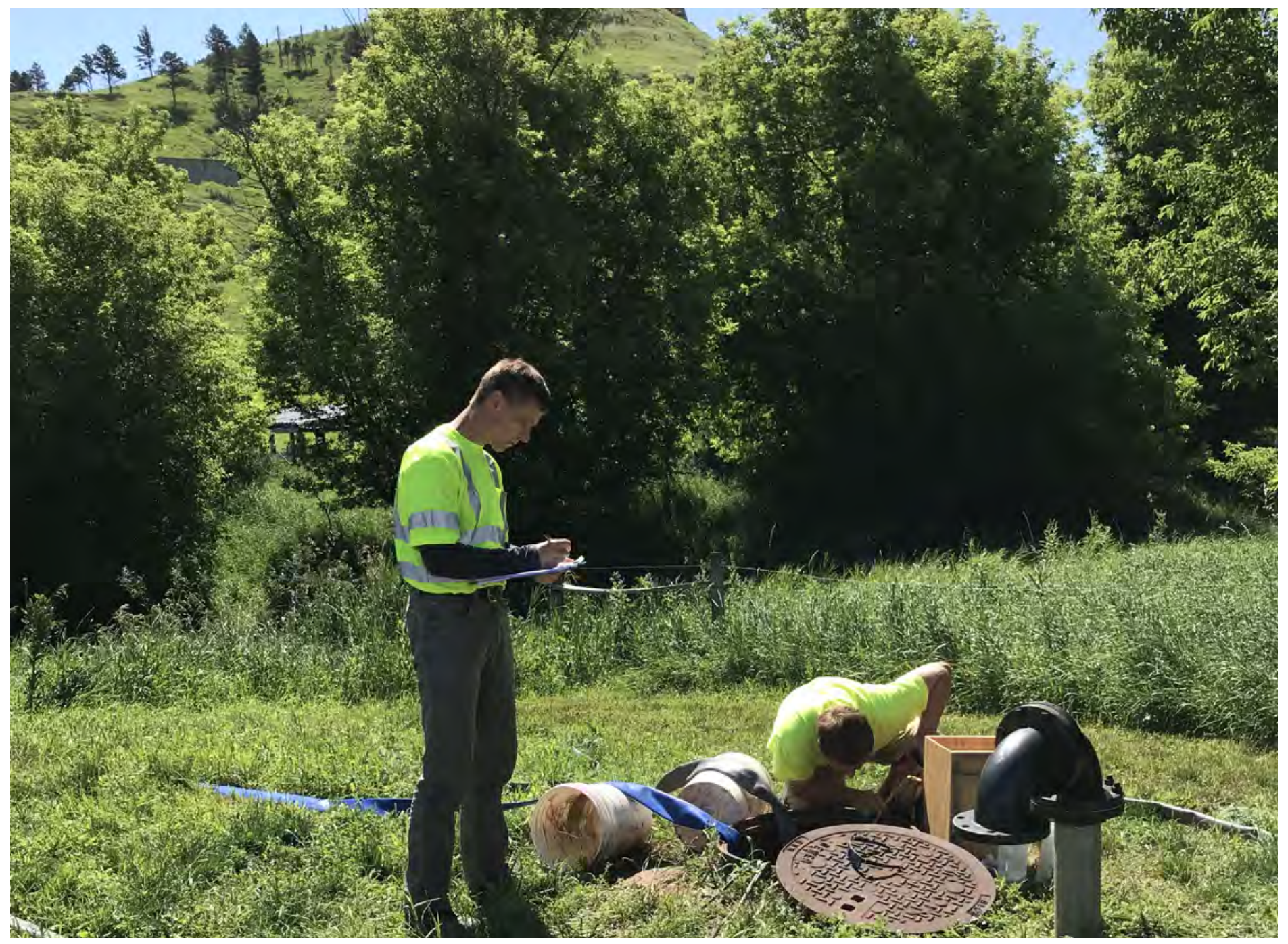

Scientific Investigations Report 2020-5097 
Cover: Photograph showing Bill Eldridge, U.S. Geological Survey, and Tanner Fenenga, City of Summerset Public Works Department, measuring water levels in a storm water access, taken in the Sun Valley Estates subdivision, Summerset, South Dakota, July 19, 2019, by Joshua Valder, U.S. Geological Survey. 


\section{Hydrogeology and Groundwater Flow in Alluvial Deposits, North Summerset, South Dakota}

By William G. Eldridge and Todd M. Anderson

Prepared in cooperation with the City of Summerset

Scientific Investigations Report 2020-5097 


\title{
U.S. Department of the Interior \\ DAVID BERNHARDT, Secretary
}

\author{
U.S. Geological Survey \\ James F. Reilly II, Director
}

U.S. Geological Survey, Reston, Virginia: 2020

For more information on the USGS - the Federal source for science about the Earth, its natural and living resources, natural hazards, and the environment-visit https://www.usgs.gov or call 1-888-ASK-USGS.

For an overview of USGS information products, including maps, imagery, and publications, visit https://store.usgs.gov/.

Any use of trade, firm, or product names is for descriptive purposes only and does not imply endorsement by the U.S. Government.

Although this information product, for the most part, is in the public domain, it also may contain copyrighted materials as noted in the text. Permission to reproduce copyrighted items must be secured from the copyright owner.

Suggested citation:

Eldridge, W.G., and Anderson, T.M., 2020, Hydrogeology and groundwater flow in alluvial deposits, north Summerset, South Dakota: U.S. Geological Survey Scientific Investigations Report 2020-5097, 31 p., https://doi.org/10.3133/ sir20205097.

Associated data for this publication:

Eldridge, W.G., 2020, Soil-Water Balance model for alluvial deposits in Summerset, South Dakota: U.S. Geological Survey data release, https://doi.org/10.5066/P9TKVMXU.

U.S. Geological Survey, 2019, USGS water data for the Nation: U.S. Geological Survey National Water Information System database, https://doi.org/10.5066/F7P55KJN.

ISSN 2328-0328 (online) 


\section{Acknowledgments}

The authors wish to acknowledge the staff of the City of Summerset, South Dakota, for their cooperation and assistance with completing this study. The authors especially thank Lonnie Harmon and Tanner Fenenga for their support and assistance with collecting data.

The authors also acknowledge U.S. Geological Survey personnel who assisted with the technical review and publication of the report. 



\section{Contents}

Acknowledgments ……...................................................................................................................

Abstract

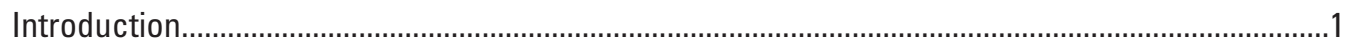

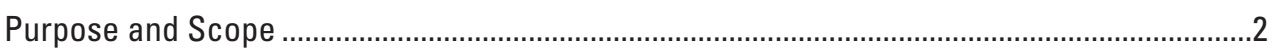

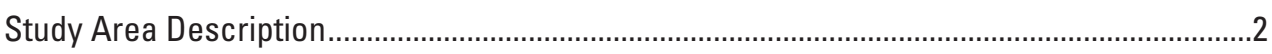

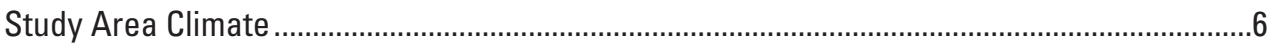

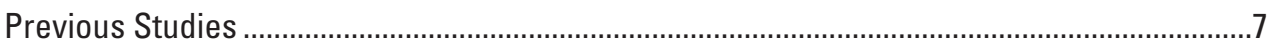

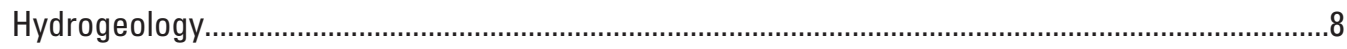

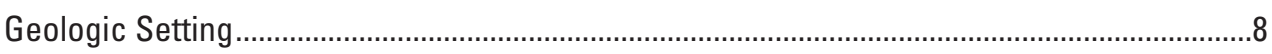

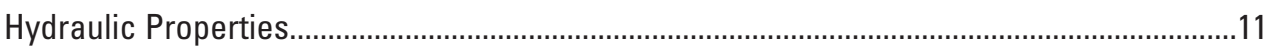

Estimates from Previous Studies ....................................................................................11

Aquifer Tests with Slugs ................................................................................................11

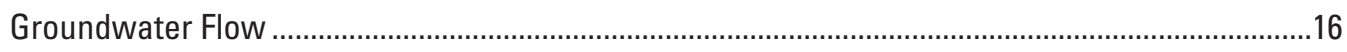

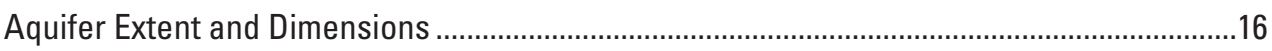

Generalized Potentiometric-Surface and Groundwater-Flow Map ......................................16

Sources and Estimates of Recharge and Discharge in the Study Area .................................22

Estimated Groundwater Budget Components .........................................................................2

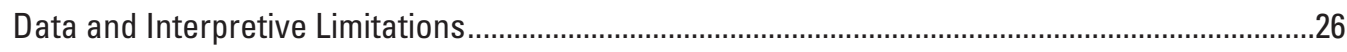

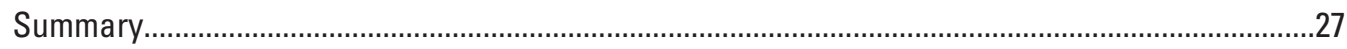

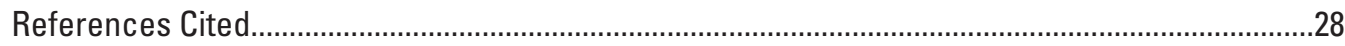

\section{Figures}

1. Map showing study area boundary, area of interest boundary, alluvial deposits, and the Sun Valley Estates subdivision, north Summerset, South Dakota .........................3

2. Map showing watershed boundaries used to define the area of interest for north Summerset, South Dakota

3. Map showing generalized land cover in the study area, north Summerset, South Dakota

4. Graph showing composite daily precipitation from National Oceanic and Atmospheric Administration sites US1SDMD0032, US1SDMD0031, US1SDPN0056, and USC00396947 and daily minimum and maximum temperatures from National Oceanic and Atmospheric Administration site USC00396947 near Summerset, South Dakota, from 2017 to 2019

5. Graph showing monthly absolute and cumulative departures from normal for precipitation from 2017 to 2019, north Summerset, South Dakota.

6. Stratigraphic columnar section showing stratigraphy of north Summerset, South Dakota ...

7. Map showing surficial geology of the study area, north Summerset, South Dakota .....10

8. Image showing the inside of a trench dug in the Sun Valley Estates subdivision showing a layer of mostly cobble- and boulder-sized clasts between fine-grained clays and silts within the alluvium in north Summerset, South Dakota, with sunglasses about 5 inches in length to provide scale.

9. Geologic cross section of the study area from $A$ to $A^{\prime}$, north Summerset, South Dakota..... 
10. Simplified conceptual model of the alluvial aquifer in north Summerset, South Dakota

11. Map showing estimated alluvial deposit thickness in north Summerset, South Dakota

12. Hydrographs showing U.S. Geological Survey wells 441318103220001 , 441319103215701, and 441326103215101 in north Summerset, South Dakota

13. Map showing generalized potentiometric-surface map of alluvial deposits in north Summerset, South Dakota, using the maximum water-level elevation on record and land-surface contours.

14. Map showing Soil-Water Balance-modeled spatial distribution of recharge and contours of potential evapotranspiration for 2019, north Summerset, South Dakota.....24

\section{Tables}

1. National Oceanic and Atmospheric Administration climate stations near Summerset, South Dakota, used for climate data summaries.

2. Hydraulic properties from studies of alluvial deposits along Rapid Creek, South Dakota

3. Well and aquifer characteristics used to estimate hydraulic conductivity in alluvial deposits for north Summerset, South Dakota

4. Summary of slug-test results with estimated hydraulic conductivity, north Summerset, South Dakota.

5. Water-level data used for potentiometric-surface map construction for north Summerset, South Dakota.

6. Inflows into Summerset water reclamation facility and estimates of discharge to Stagebarn Canyon drainage with streamflow losses to the alluvial aquifer for north Summerset, South Dakota ...

7. Estimated groundwater budget components for the alluvial aquifer of north Summerset, South Dakota, 2019...

\section{Conversion Factors}

U.S. customary units to International System of Units

\begin{tabular}{|c|c|c|}
\hline Multiply & By & To obtain \\
\hline \multicolumn{3}{|c|}{ Length } \\
\hline inch (in.) & 2.54 & centimeter $(\mathrm{cm})$ \\
\hline inch (in.) & 25.4 & millimeter $(\mathrm{mm})$ \\
\hline foot $(\mathrm{ft})$ & 0.3048 & meter $(\mathrm{m})$ \\
\hline mile (mi) & 1.609 & kilometer $(\mathrm{km})$ \\
\hline \multicolumn{3}{|c|}{ Area } \\
\hline square foot $\left(\mathrm{ft}^{2}\right)$ & 929.0 & square centimeter $\left(\mathrm{cm}^{2}\right)$ \\
\hline square foot $\left(\mathrm{ft}^{2}\right)$ & 0.09290 & square meter $\left(\mathrm{m}^{2}\right)$ \\
\hline square mile $\left(\mathrm{mi}^{2}\right)$ & 259.0 & hectare (ha) \\
\hline square mile $\left(\mathrm{mi}^{2}\right)$ & 2.590 & square kilometer $\left(\mathrm{km}^{2}\right)$ \\
\hline
\end{tabular}




\begin{tabular}{lcl}
\hline \multicolumn{1}{c}{ Multiply } & By & \multicolumn{1}{c}{ To obtain } \\
\hline million gallons (Mgal) & Volume & \\
\hline & 3,785 & cubic meter $\left(\mathrm{m}^{3}\right)$ \\
\hline foot per day (ft/d) & Flow rate & \\
cubic foot per second (ft3/s) & 0.3048 & meter per day $(\mathrm{m} / \mathrm{d})$ \\
cubic foot per day $(\mathrm{ft} 3 / \mathrm{d})$ & 0.02832 & cubic meter per second $\left(\mathrm{m}^{3} / \mathrm{s}\right)$ \\
gallon per minute $(\mathrm{gal} / \mathrm{min})$ & 0.02832 & cubic meter per day $\left(\mathrm{m}^{3} / \mathrm{d}\right)$ \\
gallon per day (gal/d) & 0.06309 & liter per second $(\mathrm{L} / \mathrm{s})$ \\
\hline & 0.003785 & cubic meter per day $\left(\mathrm{m}^{3} / \mathrm{d}\right)$ \\
\hline foot squared per day $(\mathrm{ft} 2 / \mathrm{d})$ & Transmissivity & \\
\hline
\end{tabular}

International System of Units to U.S. customary units

\begin{tabular}{|c|c|c|}
\hline Multiply & By & To obtain \\
\hline \multicolumn{3}{|c|}{ Length } \\
\hline meter (m) & 3.281 & foot $(\mathrm{ft})$ \\
\hline meter (m) & 1.094 & yard (yd) \\
\hline
\end{tabular}

Temperature in degrees Fahrenheit $\left({ }^{\circ} \mathrm{F}\right)$ may be converted to degrees Celsius $\left({ }^{\circ} \mathrm{C}\right)$ as follows:

$$
{ }^{\circ} \mathrm{C}=\left({ }^{\circ} \mathrm{F}-32\right) / 1.8 .
$$

\title{
Datum
}

Vertical coordinate information is referenced to the North American Vertical Datum of 1988 (NAVD 88).

Horizontal coordinate information is referenced to the North American Datum of 1983 (NAD 83).

Elevation, as used in this report, refers to distance above the vertical datum.

\section{Abbreviations}

\author{
gSSURGO Gridded Soil Survey Geographic \\ NOAA National Oceanic and Atmospheric Administration \\ NWIS National Water Information System \\ PVC polyvinyl chloride \\ SWB Soil-Water Balance [model] \\ USGS U.S. Geological Survey
}





\title{
Hydrogeology and Groundwater Flow in Alluvial Deposits, North Summerset, South Dakota
}

\author{
By William G. Eldridge and Todd M. Anderson
}

\section{Abstract}

The city of Summerset is a growing community in west South Dakota. The Sun Valley Estates subdivision in the north part of the city was developed on unconsolidated deposits surrounded by steep terrain. During years with greater than normal precipitation, particularly in 2019, groundwater levels increased in the unconsolidated deposits and caused damage to stormwater systems, sewer infrastructure, and houses with basements. The U.S. Geological Survey, in cooperation with the City of Summerset, completed a study of the hydrogeology and groundwater flow in the alluvial aquifer part of the unconsolidated deposits in north Summerset to understand the groundwater system in the area and to provide hydrogeologic information in support of future development planning.

The study area included most of the Sun Valley Estates subdivision in the north part of the city of Summerset in the east Black Hills of west South Dakota. About 0.7 square mile of water-bearing alluvial deposits is included in the study area. Precipitation in the study area from 2017 to 2019 was compared to the monthly normal values at a nearby climate site. The largest departure from normal was in May 2019 with precipitation exceeding the monthly normal by about 5 inches (in.). All months in 2019, except March, exceeded the monthly normal precipitation. Cumulative departure from normal precipitation in 2019 increased from about 4 in. greater than normal in January to about 18 in. greater than normal in December.

The geologic setting of the study area is characterized by the surrounding Black Hills. Unconsolidated Quaternaryage deposits overlie consolidated to partially consolidated Mesozoic-age and Paleozoic-age shales, sandstones, and limestones. Surficial deposits of alluvium and other unconsolidated deposits are the primary surficial geologic units in the study area and form the components of the alluvium hydrogeologic unit of the study area. Results from previous studies of alluvium along nearby Rapid Creek estimated hydraulic conductivity to range from 89 to 2,292 feet per day (ft/d), transmissivity to range from 1,001 to 32,083 feet squared per day, and storage coefficients to range from 0.0002 to 0.16 . Hydraulic conductivity and transmissivity generally decreased downstream along Rapid Creek (west to east). Slug tests were completed August 16, 2019, at two observation wells completed in the alluvial aquifer in the Sun Valley Estates subdivision to determine hydraulic conductivity. Hydraulic conductivity estimated from AQTESOLV curve-fitting analysis using the Bouwer-Rice method for all slug-in and slug-out trials from two observation wells in the study ranged from 0.20 to $0.26 \mathrm{ft} / \mathrm{d}$ for well 441318103220001 (SunValley1 well) and from 0.54 to $14 \mathrm{ft} / \mathrm{d}$ for well 441319103215701 (SunValley2 well). The mean, median, and standard deviation of all trials at both wells were $4.3 \mathrm{ft} / \mathrm{d}, 0.8 \mathrm{ft} / \mathrm{d}$, and $5.6 \mathrm{ft} / \mathrm{d}$, respectively.

The extent of the alluvial aquifer was determined by geologic maps and lithologic logs. Alluvial deposits in the study area extend to about 1 mile in the north-south direction and about 1.5 miles in the southeast-northwest direction. The direction of groundwater flow was estimated using water-level records and topographic maps. The resulting potentiometric map indicated that groundwater in the alluvial aquifer under the Sun Valley Estates subdivision originates from higher elevations of the west part of the area of interest and from streams in the southeast part. Recharge and evapotranspiration estimates were results from a Soil-Water Balance model that calculated a matrix of recharge for 2019 with values ranging from 0 to $11.4 \mathrm{in}$. and an annual mean value of $5.1 \mathrm{in}$. across the study area. Soil-Water Balance-estimated potential evapotranspiration for 2019 ranged from 28.90 to $28.75 \mathrm{in}$. and the estimated annual mean was $28.86 \mathrm{in}$. across the study area. Estimated groundwater budget components for the alluvial aquifer in the area of interest included inflows and outflows. Total estimated groundwater budget components for inflows for 2019 were about 66 percent from recharge, 33 percent from streamflow, and 1 percent from inflow from adjacent aquifers. Total estimated outflows were about 99-percent evapotranspiration and less than 1-percent outflow to adjacent aquifers.

\section{Introduction}

The city of Summerset is a growing community in west South Dakota. The Sun Valley Estates subdivision in the north part of the city was developed on unconsolidated deposits surrounded by steep terrain (fig. 1). After 2005, the subdivision experienced rapid housing growth, and during years with greater than normal precipitation, particularly in 2019, 
groundwater levels increased in the unconsolidated deposits and caused damage to stormwater systems, sewer infrastructure, and houses with basements. The U.S. Geological Survey (USGS), in cooperation with the City of Summerset, completed a study of the hydrogeology and groundwater flow in the alluvial aquifer part of the unconsolidated deposits in north Summerset to understand the groundwater system in the area and to provide hydrogeologic information in support of future development planning.

\section{Purpose and Scope}

The purpose of this report is to characterize the hydrogeology and estimate the groundwater flow of the alluvial aquifer in the Sun Valley Estates subdivision in north Summerset, South Dakota. The hydrogeologic characterization and groundwater-flow map could be used by managers to assist with future city planning and engineering projects. The scope of this report includes part of the alluvial aquifer in north Summerset and climate data from 2017 to 2019. Data for the study included 31 lithologic logs obtained from the South Dakota Department of Environment and Natural Resources and the City of Summerset (South Dakota Department of Environment and Natural Resources, 2019; Eldridge, 2020) and water-level measurements at five wells from the USGS National Water Information System (NWIS; U.S. Geological Survey, 2019). The hydrogeologic characterization of the alluvial aquifer was based on lithologic logs, water-level data, and aquifer testing. Water-level and digital elevation data (U.S. Geological Survey, 2017) were used to estimate the potentiometric surface and direction of groundwater flow for the alluvial aquifer. Hydrogeologic characterization of the underlying bedrock formations in the study area was not included in this report because it is outside the scope of this study and was previously documented (Lisenbee and Hargrave, 2005; Redden, 2018).

\section{Study Area Description}

The study area included the Sun Valley Estates subdivision in the north part of the city of Summerset in the east Black Hills of west South Dakota (fig. 1). The rectangular study area included unnamed ephemeral streams near the Sun Valley Estates subdivision and parts of the Stagebarn Canyon drainage and water reclamation facility outflow (fig. 1). The study area boundary was defined to maximize use of available lithologic and water-level data required to create lithologic thickness and potentiometric-surface maps. About 0.7 square mile $\left(\mathrm{mi}^{2}\right)$ of the alluvial aquifer is included in the study area. The land-surface elevation of the study area ranges from about 3,040 to 5,739 feet (ft) above the North American Vertical Datum of 1988. A smaller area of interest within the rectangular study area (fig. 1) was defined by the approximate watershed boundaries of streams. The boundaries of the area of interest simplified construction of potentiometric-surface and lithologic thickness maps because the northwest and southeast boundaries of the smaller area of interest were assumed to be groundwater no-flow boundaries for the alluvial aquifer.

Watersheds that contribute surface-water runoff to the study area were used to determine the boundaries of the area of interest (fig. 2). The Stagebarn Canyon watershed below the Sun Valley Estates subdivision was defined by a delineation point on the northeast boundary of the area of interest and is about $24.1 \mathrm{mi}^{2}$ (fig. 2; U.S. Army Corps of Engineers, 2018). The extent of the Stagebarn Canyon watershed below the Sun Valley Estates subdivision ranges from about 0.5 mile (mi) north of the Sun Valley Estates subdivision to about 4 mi east into the east foothills of the Black Hills (fig. 2). The watershed also includes drainages from steep terrain, canyons, and parts of Interstate 90 and Sturgis Road. A smaller subwatershed within the boundaries of the study area is about $1.3 \mathrm{mi}^{2}$ and was delineated from a point along an ephemeral stream segment north of the Stagebarn Canyon drainage and the east boundary of the study area (fig. 2). The boundary of this smaller subwatershed was used to define the north, west, and south boundaries of the area of interest (fig. 1). The area of interest excludes the watershed above the confluence of the Stagebarn Canyon drainage and the water reclamation outflow. The subwatershed ranges from the east foothills of the Black Hills to $0.5 \mathrm{mi}$ north of the Sun Valley Estates subdivision. The east boundary of the area of interest was represented by part of the northeast boundary of the Stagebarn Canyon watershed so that the area of interest could include most of the Sun Valley Estates subdivision.

Land cover in the rectangular study area includes a variety of types (fig. 3; Yang and others, 2018). Evergreen forest has the largest coverage at about 41 percent of the total land cover in the study area. The land-cover types with the second and third largest coverages are herbaceous and shrub/ scrub with 25 percent and 13 percent of the total land cover in the study area, respectively. Developed land, including low intensity, medium intensity, and open space, accounts for about 18 percent of the land cover in the study area. Emergent herbaceous wetlands and woody wetlands are about 2 percent of the land cover, and high intensity developed lands are less than 1 percent. The lowest land-cover percentages are deciduous forest, hay/pasture, and open water with $0.1,0.06$, and 0.02 percent of the total land cover in the study area, respectively.

The Sun Valley Estates subdivision started development in 2005 - the same year that Summerset was incorporated as a city and began to issue building permits (City of Summerset, 2016). Most building permits in the subdivision were issued from 2005 to 2009 and at a lower rate from 2010 to 2014. The most severe basement flooding observed in 2019 was in the developed, high intensity land-use classification parts in the study area and included houses along the south side of Steamboat Road and the west side of Sun Valley Drive (Lonnie Harmon, Summerset City Manager, oral commun., 2019; fig. 3). 


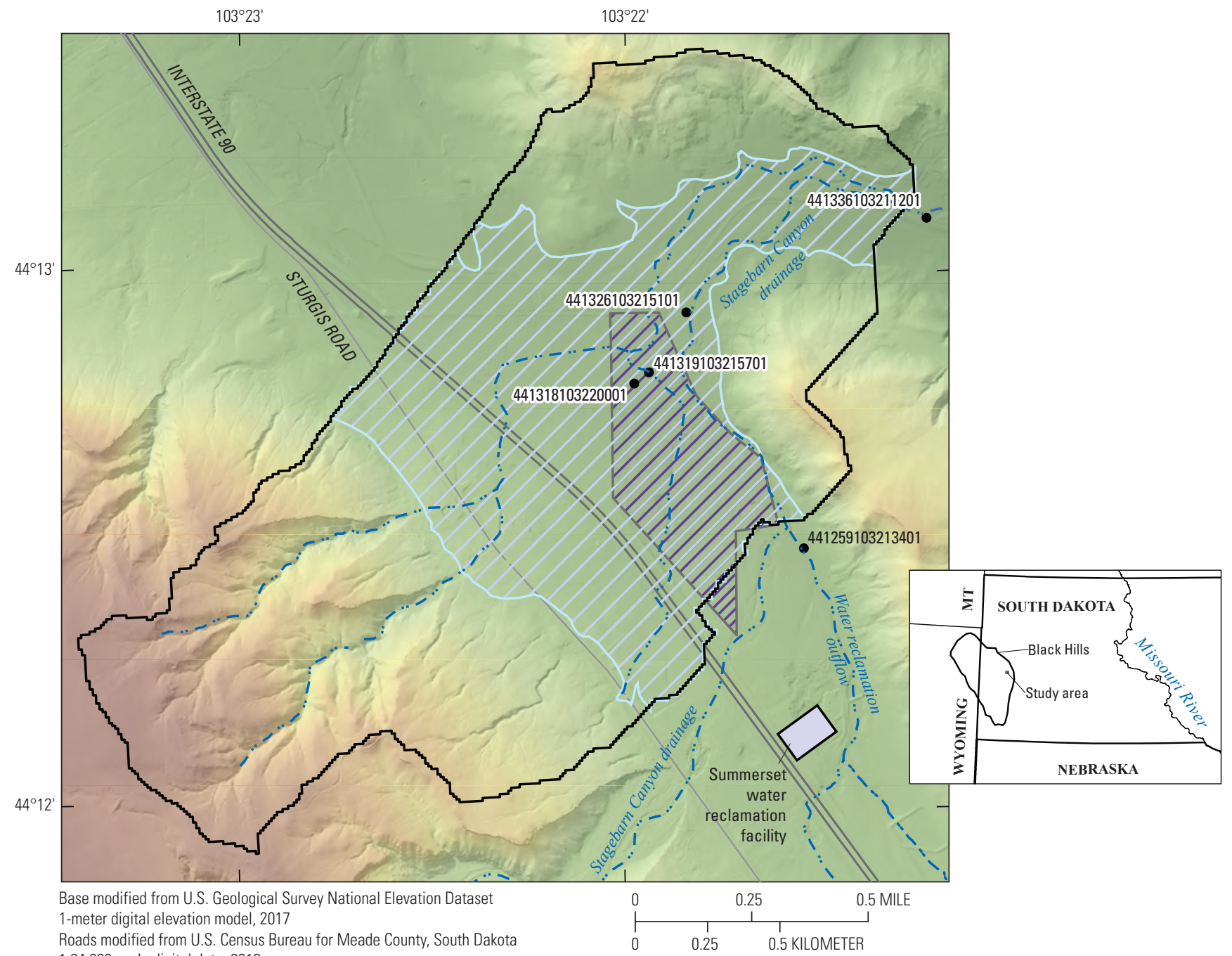

1:24,000-scale digital data, 2018

Universal Transverse Mercator projection, Zone 13

\section{EXPLANATION}

Elevation, in feet above the North American Vertical Datum of 1988

5,739

3,040

Unconsolidated (including alluvial) depositsModified from Lisenbee and Hargrave (2005) and Redden (2018)

Zun Valley Estates subdivision

- Study area boundary

- Area of interest boundary

- .. - Ephemeral stream

- Climate centroid

441319103215701

U.S. Geological Survey well and identifier

US1DPN0056

National Oceanic and Atmospheric Administration climate station and identifier

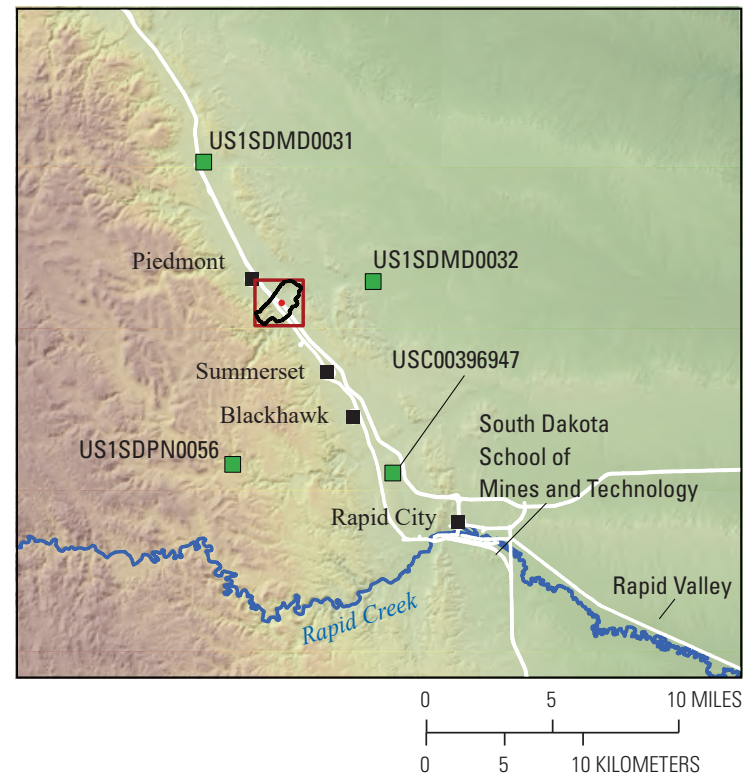

Figure 1. Study area boundary, area of interest boundary, alluvial deposits, and the Sun Valley Estates subdivision, north Summerset, South Dakota. 


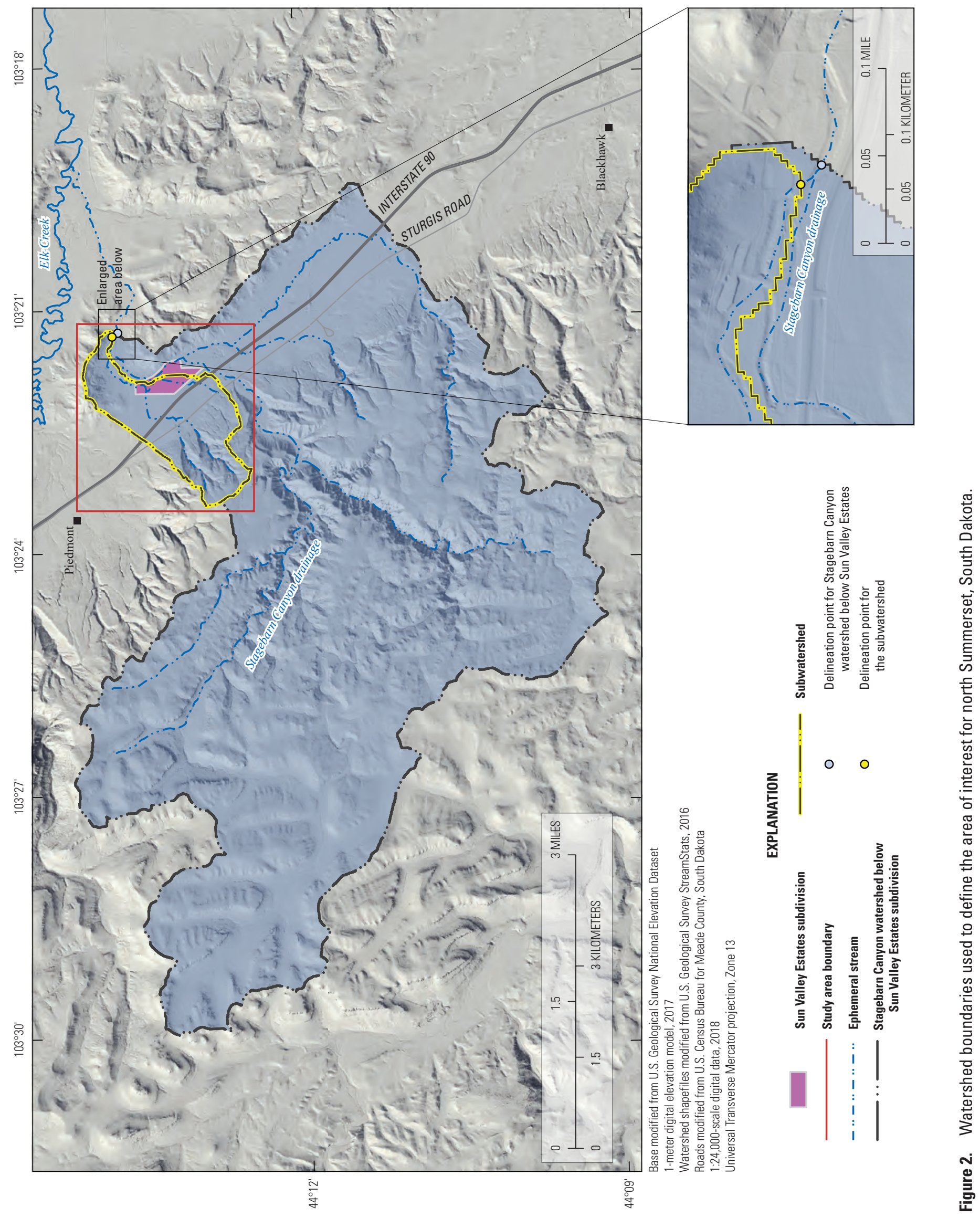




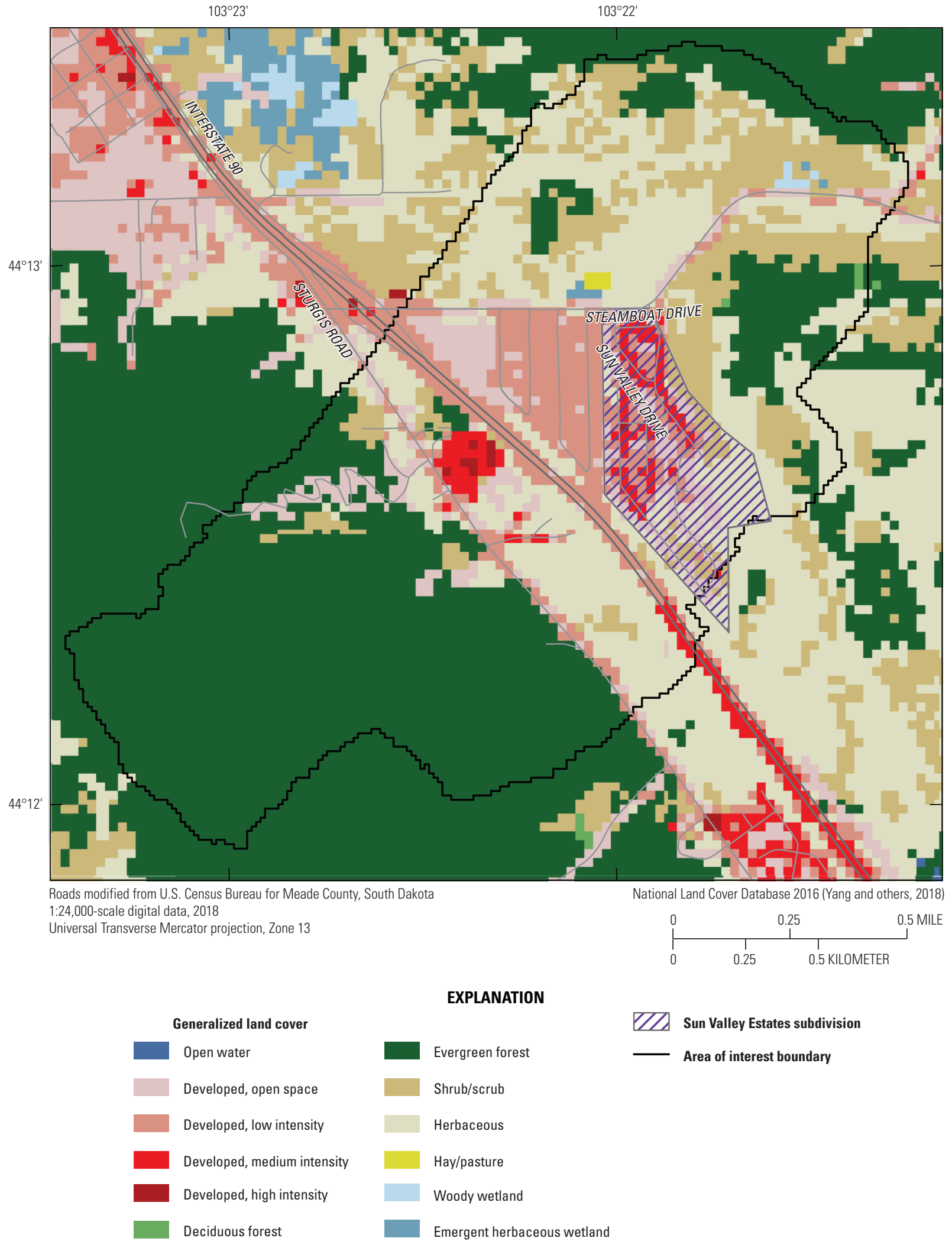

Figure 3. Generalized land cover in the study area, north Summerset, South Dakota. 


\section{Study Area Climate}

The climate of the Black Hills is semiarid and continental with generally low precipitation, hot summers, cold winters, and extreme variations in precipitation and temperature (Driscoll and others, 2002; KellerLynn, 2009). Annual mean precipitation for 1981-2010 in the Black Hills ranged spatially from about 16 to more than 32 inches (in.; PRISM Climate Group, 2014). The annual mean precipitation in the study area during the study period in 2017, 2018, and 2019 was $14.2,25.7$, and 33.5 in., respectively, and was calculated by inverse-distance weighting daily precipitation measurements from four National Oceanic and Atmospheric Administration (NOAA) climate stations (National Oceanic and Atmospheric Administration, 2019b) near the study area (fig. 1; table 1). The estimated maximum daily precipitation in the study area from 2017 to 2019 was 2.6 in. on May 22, 2019 (fig. 4). Daily minimum and maximum temperatures near the study area were available only from NOAA site USC00396947 (Rapid City 4 NW, SD US) for 2017-19 (fig. 1; table 1). Daily maximum temperatures at NOAA site USC00396947 from 2017 to 2019 ranged from 100 to -4 degrees Fahrenheit $\left({ }^{\circ} \mathrm{F}\right)$, and daily minimum temperatures ranged from 72 to $-19^{\circ} \mathrm{F}$ (fig. 4).

Daily precipitation measurements in the study area from 2017 to 2019 were summed to compute monthly values, and the monthly values were compared to monthly normals determined by NOAA for climate site USC00396947 from 1981 to 2010 (National Oceanic and Atmospheric Administration, 2019c). Climate normals are means of climatological measurements over three decades and include temperature, precipitation, snowfall, and other measurements (National Oceanic and Atmospheric Administration, 2019c). NOAA site USC00396947 was the only climate station near the study area with climate normals for precipitation for 1981-2010. Inverse-distance weighting was used to calculate daily precipitation for the study area with data from the four NOAA climate stations in table 1. Distances were calculated from the climate station to a climate centroid point in the study area (fig. 1). The difference between the inverse-distance-weighted monthly precipitation and the monthly normal precipitation from USC00396947 (departure from normal) and the cumulative monthly difference between the two values (cumulative departure from normal) are plotted in figure 5. The largest departure from normal was in May 2019 when precipitation exceeded the monthly normal by about 5 in. In 2017, six months were less than normal and six months were less than 0.5 in. greater than normal or near normal. In 2018, eight months were greater than normal with June 2018 nearly 4 in. greater than normal and four months were at or less than normal by less than $1 \mathrm{in.}$. All months in 2019, except March, exceeded the monthly normal precipitation. The cumulative departure from normal precipitation in 2019 increased from about 4 in. greater than normal in January to about 18 in. greater than normal in December. The high departure from normal precipitation in 2019 , and the increasing cumulative departure from normal in 2019, relative to 2017 and 2018, likely caused high groundwater levels in the alluvial aquifer underlying the Sun Valley Estates subdivision and contributed to basement flooding and infrastructure damage.

Table 1. National Oceanic and Atmospheric Administration climate stations near Summerset, South Dakota, used for climate data summaries.

[NOAA, National Oceanic and Atmospheric Administration; NAD 83, North American Datum of 1983; MM/DD/YYYY, month/day/year; mi, mile; E, east; SD, South Dakota; US, United States; N, north; WNW, west-northwest; NW, northwest]

\begin{tabular}{|c|c|c|c|c|c|c|}
\hline $\begin{array}{l}\text { NOAA climate } \\
\text { station name }^{1}\end{array}$ & $\begin{array}{l}\text { NOAA climate } \\
\text { station identifier }{ }^{1}\end{array}$ & $\begin{array}{c}\text { Latitude } \\
\text { (decimal degrees, } \\
\text { NAD 83) }\end{array}$ & $\begin{array}{c}\text { Longitude } \\
\text { (decimal degrees, } \\
\text { NAD 83) }\end{array}$ & $\begin{array}{l}\text { Period of record } \\
\text { (MM/DD/YYYY) }\end{array}$ & $\begin{array}{l}\text { Distance from } \\
\text { centroid of } \\
\text { study area }(\mathrm{mi})\end{array}$ & $\begin{array}{c}\text { Available records } \\
\text { used in study }\end{array}$ \\
\hline $\begin{array}{l}\text { PIEDMONT } 4.6 \\
\text { E, SD US }\end{array}$ & US1SDMD0032 & 44.230679 & -103.296615 & $\begin{array}{c}03 / 21 / 2004 \text { to } \\
01 / 01 / 2020\end{array}$ & 3.8 & Precipitation \\
\hline $\begin{array}{l}\text { TILFORD } 0.1 \mathrm{~N}, \\
\text { SD US }\end{array}$ & US1SDMD0031 & 44.301174 & -103.430068 & $\begin{array}{l}12 / 27 / 2011 \text { to } \\
01 / 01 / 2020\end{array}$ & 6.4 & Precipitation \\
\hline $\begin{array}{l}\text { RAPID CITY } 4 \\
\text { NW, SD US }\end{array}$ & USC00396947 & 44.120550 & -103.284170 & $\begin{array}{c}06 / 01 / 1949 \text { to } \\
01 / 01 / 2020\end{array}$ & 8.1 & $\begin{array}{l}\text { Precipitation, } \\
\text { minimum and } \\
\text { maximum tem- } \\
\text { peratures }\end{array}$ \\
\hline
\end{tabular}

1National Oceanic and Atmospheric Administration (2019a). 


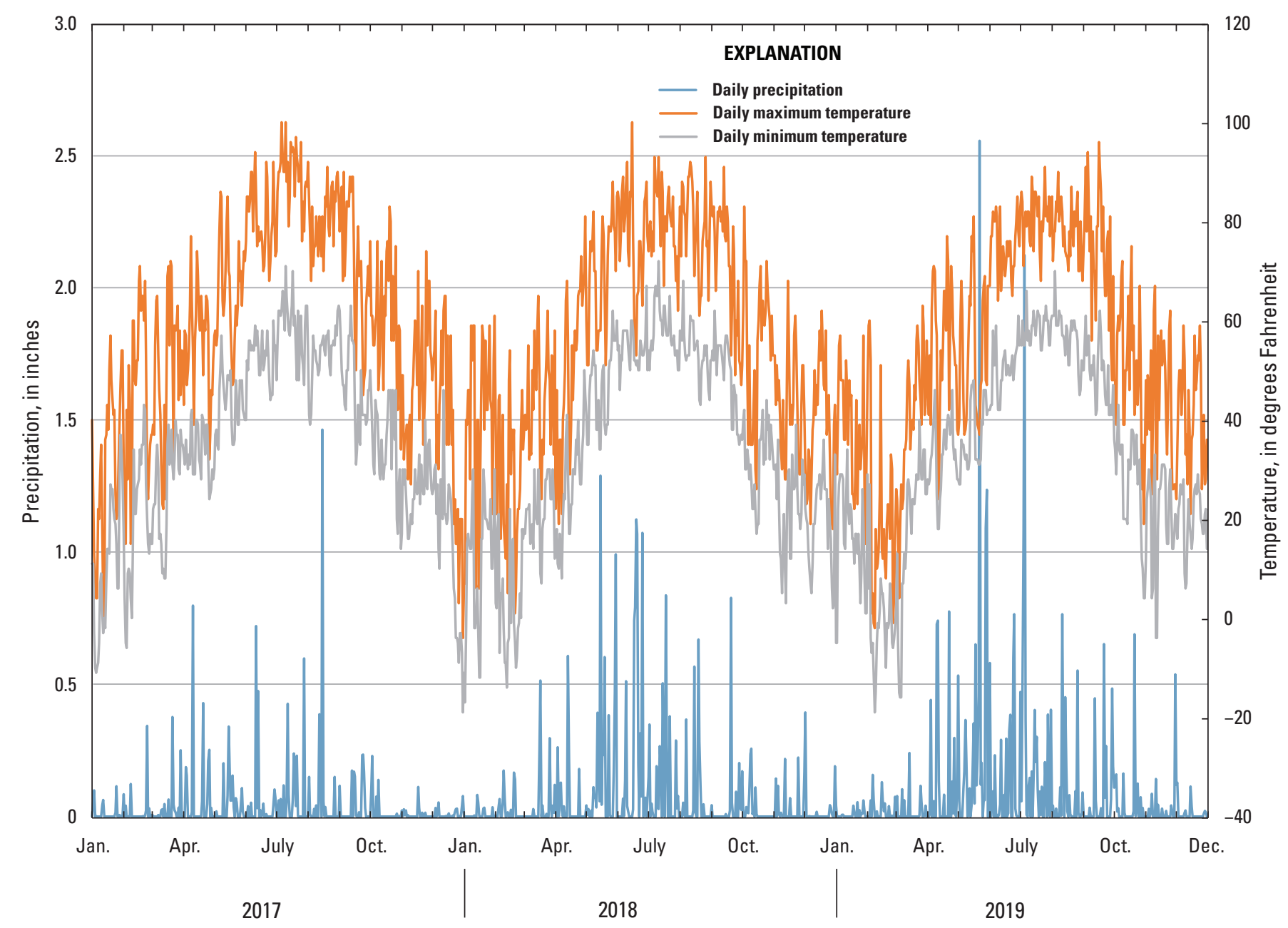

Figure 4. Composite daily precipitation from National Oceanic and Atmospheric Administration sites US1SDMD0032, US1SDMD0031, US1SDPN0056, and USC00396947 and daily minimum and maximum temperatures from National Oceanic and Atmospheric Administration site USC00396947 near Summerset, South Dakota, from 2017 to 2019.

\section{Previous Studies}

Previous studies of the area include regional hydrogeologic studies of the Black Hills, geologic maps, flood risk maps, and hydrogeologic characterizations. No previous studies were found that specifically focused on the groundwater conditions of the city of Summerset; however, data from several studies were relevant to the study area because of shared hydrogeologic characteristics. Driscoll (1994) and Driscoll and others (2002) described the hydrology of the Black Hills, including major aquifers of the region, as part of a larger hydrogeologic study of the Black Hills. Carter and others $(2001 \mathrm{a}, \mathrm{b})$ estimated hydrologic budgets for the principal aquifers in the Black Hills. Geologic maps of the region near the study area include statewide maps (Martin and others, 2004), regional maps (Carter and others, 2002; Redden and DeWitt, 2008), and quadrangle maps (Lisenbee and Hargrave, 2005; Redden, 2018). Flood inundation maps and flow frequencies were developed by the U.S. Army Corps of Engineers, the City of Summerset, and Meade County (U.S. Army Corps of Engineers, 2018). Hydrologic properties of alluvial aquifers in the east Black Hills were estimated in Rapid Valley, S. Dak. (Coker, 1981), near the South Dakota School of Mines and Technology in Rapid City, S. Dak. (Musa, 1984), and at three sites in the city limits of Rapid City, S. Dak. (Stetler, 1989; fig. 1). 


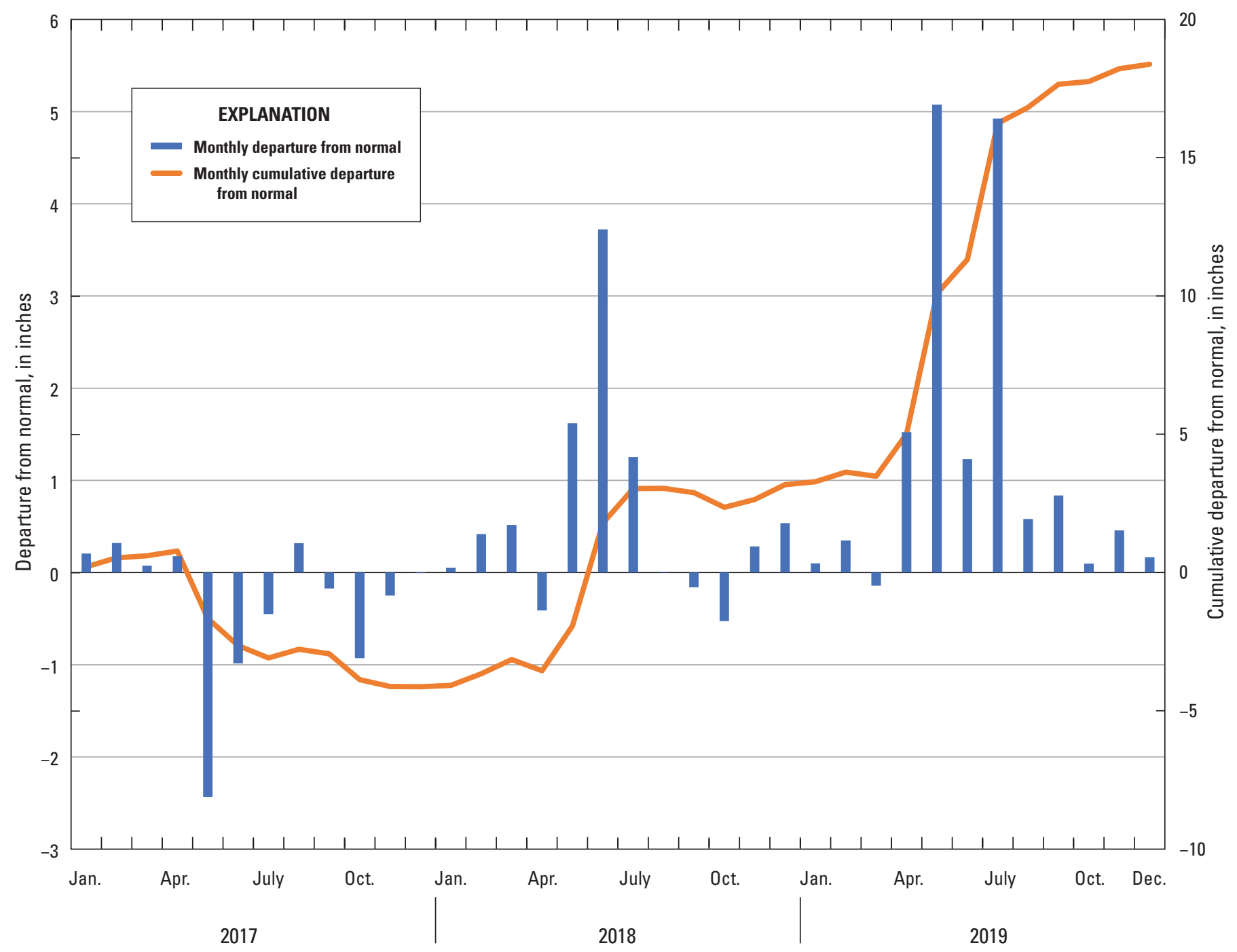

Figure 5. Monthly absolute and cumulative departures from normal for precipitation from 2017 to 2019, north Summerset, South Dakota.

\section{Hydrogeology}

The hydrogeology of the alluvial aquifer in the study area near north Summerset is affected by the geology of the east Black Hills of west South Dakota. Hydraulic properties of alluvial deposits in the east Black Hills described in this study were compiled from previous studies as described in the "Estimates from Previous Studies" section. Alluvial aquifer properties in the study area were estimated from aquifer testing completed during this study. Hydraulic conductivity estimates from previous studies ranged from 89 to 2,292 feet per day (ft/d) and estimates from aquifer testing during this study as described in the "Aquifer Tests with Slugs" section ranged from 0.20 to $14 \mathrm{ft} / \mathrm{d}$.

\section{Geologic Setting}

The geologic setting of the study area is characterized by the surrounding Black Hills. The Black Hills were formed by the Laramide orogeny and are an elongated domal uplift about $125 \mathrm{mi}$ long in the northwest-southeast direction and $60 \mathrm{mi}$ wide in the southwest-northeast direction (Feldman and Heimlich, 1980; Driscoll and others, 2002). The Laramide orogeny included regional-scale deformation, erosion, and sediment deposition (Dickinson and others, 1988). Proterozoic-age igneous and metamorphic rocks and overlying younger sedimentary rocks uplifted during the orogeny, and simultaneous and subsequent erosion of the uplift resulted in exposure of the igneous and metamorphic rocks in the core of the Black Hills surrounded by concentric rings of the remaining, once-overlaying, younger sedimentary rock (Carter and others, 2001a, b). 
In the study area, unconsolidated Quaternary-age deposits overlie consolidated to partially consolidated Mesozoic-age and Paleozoic-age shales, siltstones, sandstones, and limestones (figs. 6 and 7). Surficial deposits of alluvium and other unconsolidated deposits are the primary surficial geologic units in the study area and form the alluvial aquifer hydrogeologic unit of the study area (fig. 6). The unconsolidated materials of the alluvial aquifer hydrogeologic unit, composed of clays, silts, sands, or gravels, were deposited by streams or other bodies of flowing surface waters (Whitehead, 1996; U.S. Geological Survey, 2020).

The unconsolidated Quaternary-age units in the study area consist of alluvium, terrace deposits, alluvial fans, pediment, colluvium, and landslide deposits (figs. 6 and 7). The units generally are well-graded silty to sandy clays with gravels, cobbles, and boulders, and the alluvium consists of well-graded silty to sandy brown lean clay with gravels and cobbles (Lisenbee and Hargrave, 2005; Redden, 2018). A trench excavated in the Sun Valley Estates subdivision had a layer of cobble- to boulder-sized clasts of mostly wellrounded limestone between fine-grained clays and silts that indicated previous high flow surface waters transported the large clasts along stream valleys from higher elevations in the Black Hills (fig. 8). The limestone cobbles and boulders in the alluvium are similar in texture and color to outcrops of the Mississippian-age Madison Limestone west of the study area. The terrace deposits and colluvium in the study area generally are unstratified and consist of gravels, cobbles, boulders, and other rock fragments (Lisenbee and Hargrave, 2005; Redden, 2018). The alluvial fan and landslide deposits consist of clay to boulder-sized material from local bedrock shales, sandstones, and limestones (Lisenbee and Hargrave, 2005; Redden, 2018). The pediment stratigraphic units in the north part of the study area are elongated gentle slopes formed by unconsolidated clays, sands, and gravels (fig. 7; Lisenbee and Hargrave, 2005; Redden, 2018). The alluvial aquifer hydrogeologic unit in the study area consists of the alluvium, terrace deposits, and alluvial fan stratigraphic units (fig. 6). The alluvial aquifer is an unconfined aquifer (also called a water-table aquifer), which means the groundwater only partly fills the aquifer, the upper water surface is at atmospheric pressure, and the groundwater is free to rise and decline (Heath, 1983).

Mesozoic- and Paleozoic-age rocks underlie Quaternaryage surficial deposits in the study area and were assigned to an undifferentiated hydrogeologic unit (fig. 6). The Lakota Formation is the youngest Mesozoic unit and consists of orange-tan to white, fine-grained sandstone and a brown to light-gray mudstone (figs. 6 and 9; Lisenbee and Hargrave, 2005; Redden, 2018). Jurassic-age units - including Morrison Formation (shale), Unkpapa Sandstone (fine-grained sandstone), and Sundance Formation (sandstone and shale) underlie the Lakota Formation (figs. 6 and 9). Red, sandy shale and siltstone with interbedded gypsum compose the Triassic- to Permian-age Spearfish Formation that underlies the Sundance Formation (fig. 6). The Spearfish Formation, exposed at the surface in the study area, is the formation that

\begin{tabular}{|c|c|c|c|c|c|c|}
\hline Erathem & System & Abbreviation & Stratigraphic unit & Description & $\begin{array}{c}\text { Estimated } \\
\text { thickness } \\
\text { in study area, } \\
\text { in feet }\end{array}$ & $\begin{array}{l}\text { Hydrogeologic } \\
\text { unit used for } \\
\text { the study }\end{array}$ \\
\hline \multirow{6}{*}{ Cenozoic } & \multirow{6}{*}{ Quaternary } & Qal & Alluvium & $\begin{array}{l}\text { Unconsolidated, well-graded silty to sandy brown } \\
\text { lean clay with gravels and cobbles }\end{array}$ & $10-50$ & \multirow{3}{*}{ Alluvial aquifer } \\
\hline & & Qt & $\begin{array}{l}\text { Terrace deposit } \\
\text { (undifferentiated) }\end{array}$ & Unconsolidated gravel, cobbles, and boulders & As much as 33 & \\
\hline & & Qaf & Alluvial fan & $\begin{array}{l}\text { Unconsolidated clay to boulder-sized clasts near } \\
\text { present-day drainages }\end{array}$ & As much as 35 & \\
\hline & & Qpd & Pediment & $\begin{array}{l}\text { Unconsolidated clay, sand, and gravel that form } \\
\text { elongated, gentle slopes }\end{array}$ & $?$ & \multirow{11}{*}{$\begin{array}{l}\text { Undifferentiated } \\
\text { deposits }\end{array}$} \\
\hline & & Qc & Colluvium & $\begin{array}{l}\text { Unstratified soil with cobble- to boulder-sized } \\
\text { angular clasts of locally derived rock fragments }\end{array}$ & As much as 20 & \\
\hline & & Qld & Landslide debris & $\begin{array}{l}\text { Unconsolidated blocks of local bedrock material } \\
\text { interpreted as debris flows }\end{array}$ & $?$ & \\
\hline \multirow{4}{*}{ Mesozoic } & Cretaceous & $\mathrm{KI}$ & Lakota Formation & $\begin{array}{l}\text { Orange-tan to white, fine-grained sandstone and } \\
\text { brown to light-gray mudstone }\end{array}$ & 300 & \\
\hline & \multirow{3}{*}{ Jurassic } & $\mathrm{Jm}$ & Morrison Formation & Green to maroon shale & $33-65$ & \\
\hline & & $\mathrm{Ju}$ & Unkpapa Sandstone & $\begin{array}{l}\text { Buff to white, poorly indurated, calcareous fine- } \\
\text { grained sandstone }\end{array}$ & As much as 120 & \\
\hline & & Js & Sundance Formation & $\begin{array}{l}\text { Green, glauconitic sandstone and shale in the } \\
\text { upper } 10 \text { feet, red sandstone in middle }\end{array}$ & $405-445$ & \\
\hline \multirow{4}{*}{ Paleozoic } & Triassic-Permian & kPs & Spearfish Formation & $\begin{array}{l}\text { Red siltstone, shale, and minor limestone. } \\
\text { Includes white to light-gray gypsum beds }\end{array}$ & $402-497$ & \\
\hline & \multirow[t]{2}{*}{ Permian } & $\mathrm{Pm}$ & Minnekahta Limestone & $\begin{array}{l}\text { Pinkish to pale- and purple-gray thinly bedded } \\
\text { limestone }\end{array}$ & $43-60$ & \\
\hline & & Po & Opeche Shale & Red shale and siltstone & $50-160$ & \\
\hline & Permian-Pennsylvanian & $\mathrm{PPm}$ & Minnelusa Formation & $\begin{array}{l}\text { Interbedded sandstone, dolostone, limestone, and } \\
\text { shale. Red, yellow, and gray to orange }\end{array}$ & $450-550$ & \\
\hline
\end{tabular}

Figure 6. Stratigraphy of north Summerset, South Dakota (modified from Lisenbee and Hargrave [2005] and Redden [2018]). [?, unknown] 


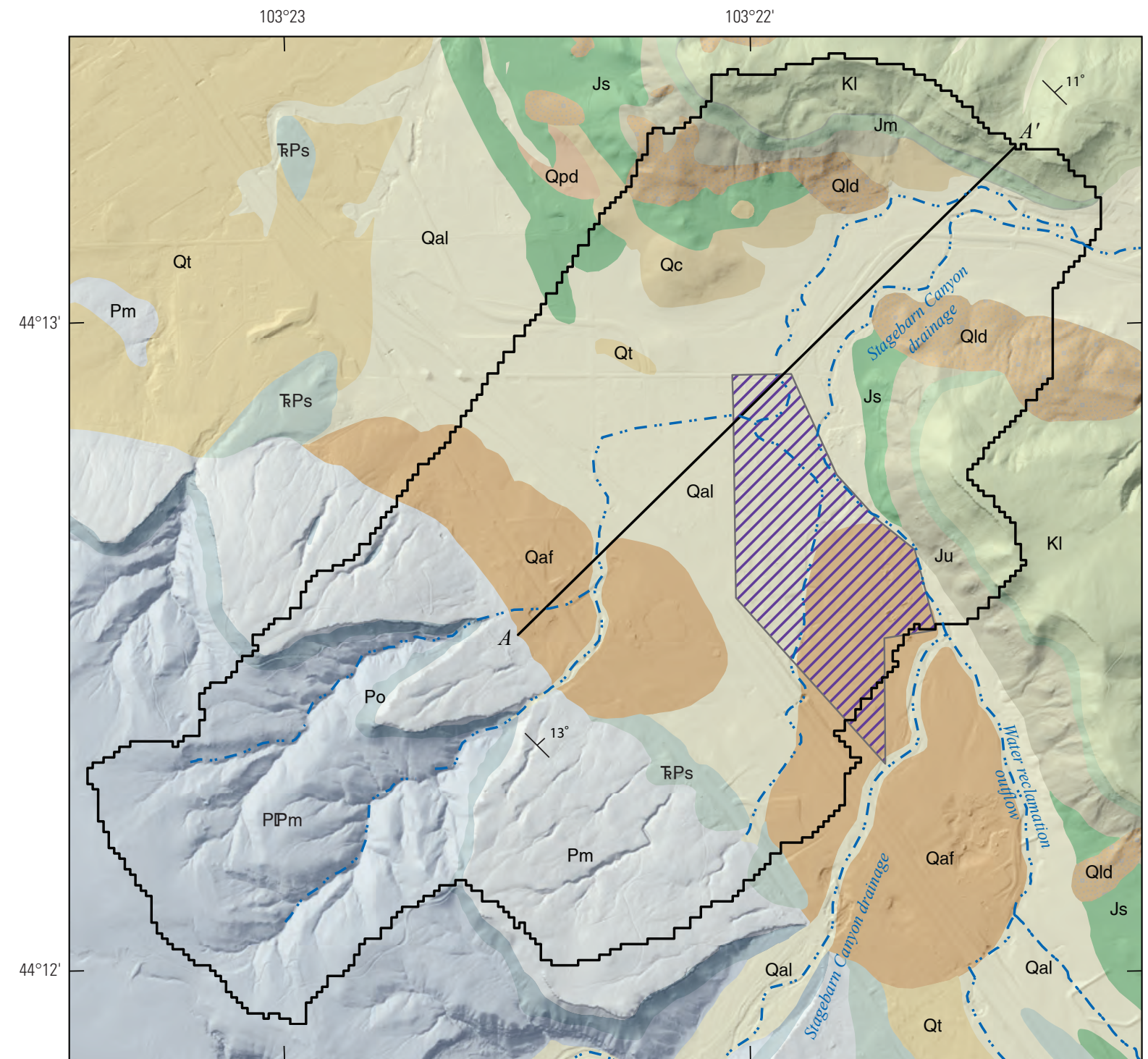

Base modified from U.S. Geological Survey National Elevation Dataset 1-meter digital elevation model, 2017

Universal Transverse Mercator projection, Zone 13

Modified from Lisenbee and Hargrave (2005) and Redden (2018)

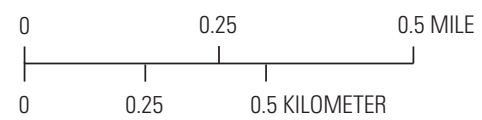

EXPLANATION

Generalized surface geology

Quaternary-age sedimentary deposit Mesozoic-age sedimentary deposit

\begin{tabular}{|ll}
\hline Qal & Alluvium \\
\hline Qaf & Alluvial fan \\
\hline Qc & Colluvium \\
\hline Qld & Landslide debris \\
\hline Qpd & Pediment \\
\hline Qt & Terrace
\end{tabular}

\begin{tabular}{|c|c|}
\hline $\mathrm{KI}$ & Lakota Formation \\
\hline $\mathrm{Jm}$ & Morrison Formation \\
\hline $\mathrm{Ju}$ & Unkpapa Sandstone \\
\hline Js & Sundance Formation \\
\hline & $\begin{array}{l}\text { ic-Paleozoic-age sedimentary } \\
\text { sit }\end{array}$ \\
\hline
\end{tabular}

Paleozoic-age sedimentary deposit

$\mathrm{Pm}$ Minnekahta Limestone

Po Opeche Shale

PPm Minnelusa Formation

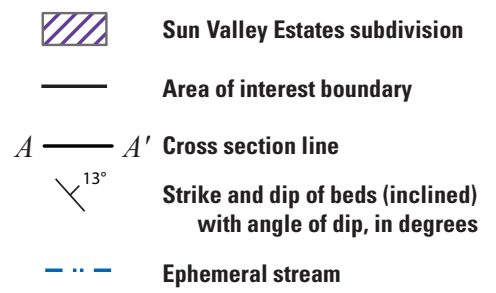

Figure 7. Surficial geology of the study area, north Summerset, South Dakota. 


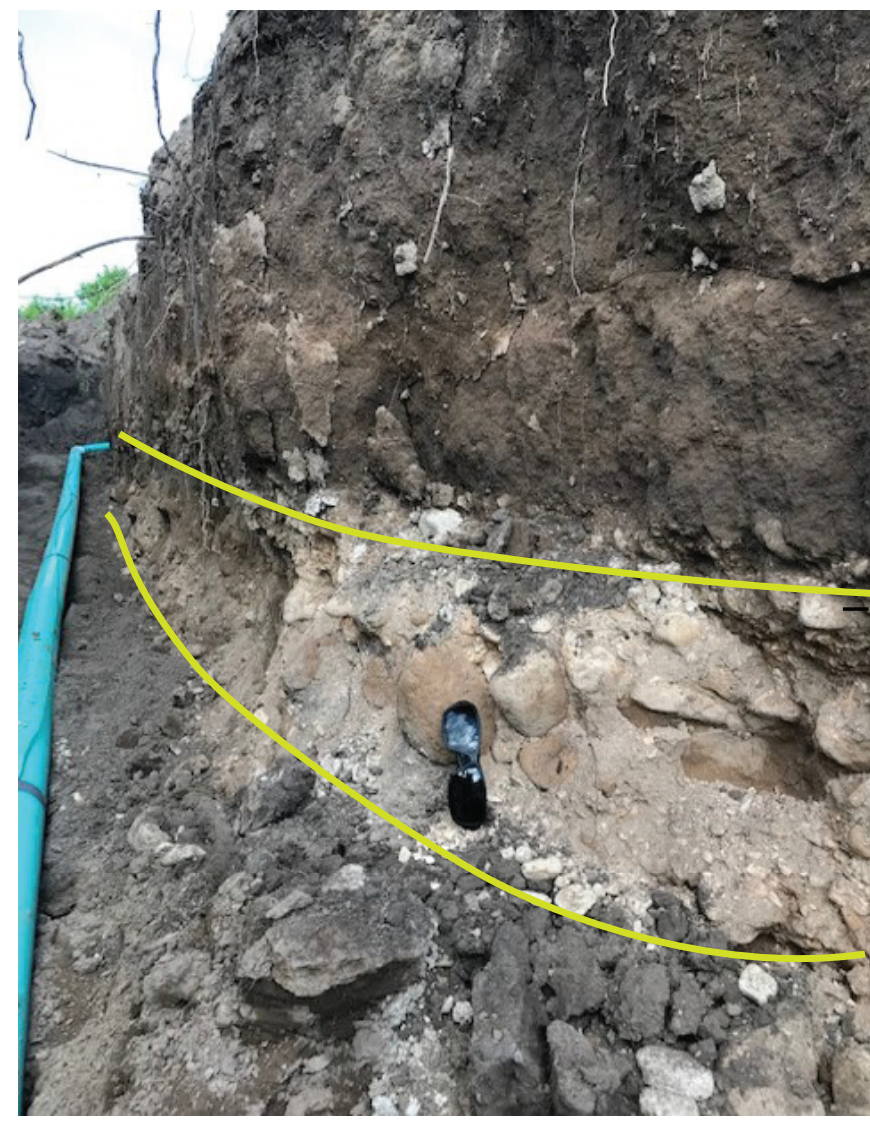

Figure 8. The inside of a trench dug in the Sun Valley Estates subdivision showing a layer of mostly cobble- and boulder-sized clasts between fine-grained clays and silts within the alluvium in north Summerset, South Dakota, with sunglasses about 5 inches in length to provide scale.

primarily underlies the Quaternary-age deposits in the Sun Valley Estates subdivision (fig. 9). Paleozoic-age units that underlie the Spearfish Formation include the Permian-age Minnekahta Limestone, Permian-age Opeche Shale, and the Permian- to Pennsylvanian-age Minnelusa Formation. These units are exposed at the surface in the higher elevation and steep terrain southwest of the study area (fig. 7; Lisenbee and Hargrave, 2005; Redden, 2018).

A geologic cross section of the sedimentary deposits underlying the study area was constructed using a digital elevation model, surficial geologic maps, and data from well logs processed with geographic information systems (fig. 9). The land surface along the $A$ to $A^{\prime}$ line (fig. 7) was determined by a digital elevation model (U.S. Geological Survey, 2017) and used to plot the Stagebarn Canyon drainage tributary in the cross section. Surficial geologic maps (Lisenbee and Hargrave, 2005; Redden, 2018) were used to determine the dip angle of the deposits underlying the alluvium. Dip angles were assumed to remain constant within the extent of the cross section. The thickness of the alluvial deposits along the $A$ to $A^{\prime}$ line (fig. 7) was estimated by determining the depth to the bottom of the alluvium from the land surface recorded in lithologic logs and water-well completion reports as described in the "Aquifer Extent and Dimensions" section. The cross section shows that the Sun Valley Estates subdivision is underlain by alluvium and alluvial fan deposits that primarily overly the Spearfish Formation (fig. 9).

\section{Hydraulic Properties}

Hydraulic properties for the alluvial aquifer in north Summerset were determined from two sources: (1) estimates of hydraulic properties from previous studies, and (2) aquifer tests at two wells in the study area. The estimates from previous studies were from sites outside the study area but in geologic materials like those in the study area; therefore, they were considered relevant to the alluvial aquifer material in the study area.

\section{Estimates from Previous Studies}

Hydraulic properties of alluvial deposits were measured by several studies near Rapid Creek, a perennial stream about $12 \mathrm{mi}$ south of the study area (fig. 1; table 2). Coker (1981) completed an aquifer test in east Rapid City (Rapid Valley) in alluvial deposits near Rapid Creek and estimated hydraulic conductivity, transmissivity, and the storage coefficient. Musa (1984) used a pumping test and measured drawdown from several observation wells completed in alluvial deposits along Rapid Creek in Rapid City near the South Dakota School of Mines and Technology to estimate hydraulic conductivity, transmissivity, and the storage coefficient. Stetler (1989) estimated hydraulic conductivity, transmissivity, and storage coefficients at three sites in Rapid City using pumping well aquifer tests in alluvium along Rapid Creek. Results from the three previous studies estimated hydraulic conductivity to range from 89 to $2,292 \mathrm{ft} / \mathrm{d}$, transmissivity to range from 1,001 to 32,083 feet squared per day, and storage coefficients to range from 0.0002 to 0.16 . Hydraulic conductivity and transmissivity estimates generally decreased in value as the location of the tests moved downstream along Rapid Creek (west-east).

\section{Aquifer Tests with Slugs}

A slug test is a type of aquifer test that estimates hydraulic conductivity of aquifer materials close to a well by measuring the subsequent rise (slug-out test) or fall (slug-in test) of the water level in a well in response to a nearly instantaneous change in hydraulic head. Slug tests typically are completed by adding or removing an impermeable solid object of known volume (mechanical slug) that is heavy enough to displace water and can be raised easily and lowered quickly in the water column of a well (Cunningham and Schalk, 2011). Slug tests were completed August 16, 2019, at two observation wells screened in the alluvial aquifer in the Sun Valley Estates subdivision to determine hydraulic conductivity. The wells, constructed in 2019 and named SunValley1 (SV1) 

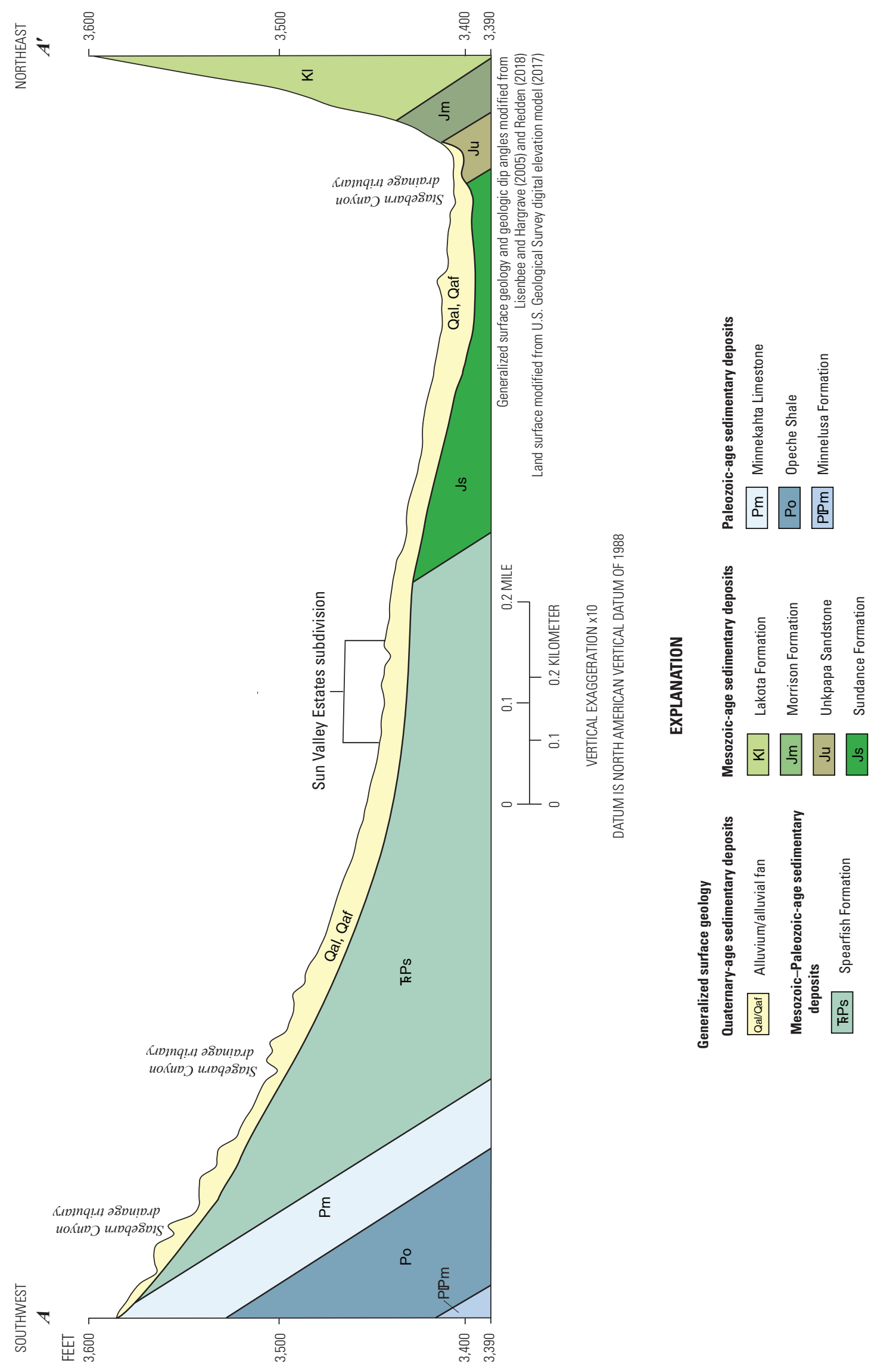

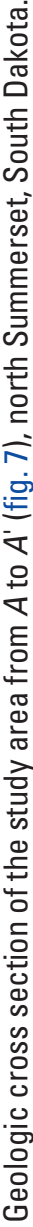

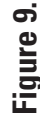


Table 2. Hydraulic properties from studies of alluvial deposits along Rapid Creek, South Dakota.

[ft/d, foot per day; $\mathrm{ft}^{2} / \mathrm{d}$, foot squared per day]

\begin{tabular}{|c|c|c|c|c|c|}
\hline Study & Study location & Method & $\begin{array}{l}\text { Hydraulic conductivity } \\
\text { (ft/d) }\end{array}$ & $\begin{array}{c}\text { Transmissivity } \\
(\mathrm{ft} 2 / \mathrm{d})\end{array}$ & $\begin{array}{c}\text { Storage coefficient } \\
\text { (unitless) }\end{array}$ \\
\hline Coker (1981) & Rapid Valley & Aquifer test & 89 & 1,001 & 0.0002 \\
\hline \multirow[t]{2}{*}{ Stetler (1989) } & Braeburn Addition ${ }^{1}$ & Aquifer test & 2,292 & 32,083 & 0.16 \\
\hline & Baken Park ${ }^{1}$ & & 264 & 2,112 & 0.16 \\
\hline
\end{tabular}

1Not shown in figures. Sites are in city limits of Rapid City, South Dakota.

and SunValley2 (SV2), were assigned USGS site numbers 441318103220001 and 441319103215701 , respectively (fig. 1).

Well and aquifer data were determined from field measurements and obtained from drillers' logs maintained by the City of Summerset (Eldridge, 2020). Although nearly identical in construction, the two wells differed by completion depth and measuring-point (stick-up) height. The total depth and measuring-point height for each well were field measured using an electric water-level tape and a surveyor tape measure, respectively, using methods described by Cunningham and Schalk (2011). Drillers' logs provided geologic and well construction information, such as the depth to the bottom of the aquifer and well screen length (South Dakota Geological Survey, 2018; South Dakota Department of Environment and Natural Resources, 2019). The bottom of the aquifer was unknown but assumed to be at or near the bottom of the well. The bottom $10 \mathrm{ft}$ of the wells were screened and were constructed with 2-in.-diameter polyvinyl chloride (PVC) casing assumed to be schedule $40 \mathrm{PVC}$.

Additional well and equipment dimensions required for hydraulic conductivity estimation included the inside radius of the well casing, the radius of downhole equipment, the radius of the packer, the radius of the well screen, the outer radius of the well skin, and the annular space diameter. These data were used as input variables to calculate hydraulic conductivity for each slug-test trial with AQTESOLV Pro version 4.50.002 (Hydrosolve, Inc., 2007). The inside radius well casing, denoted as $r(c)$ in AQTESOLV, for a schedule 40, 2-in.-diameter PVC well is about $0.083 \mathrm{ft}$. The radius of the downhole equipment (an unvented Solinst Levelogger LT F30/ M10 electronic transducer), denoted as $r(e q)$ in AQTESOLV, was $0.04 \mathrm{ft}$. None of the wells contained a packer, so the packer radius was zero. The well radius, denoted as $r(w)$ in AQTESOLV, was $0.167 \mathrm{ft}$, and the outer radius of the well skin, denoted as $r(s k)$ in AQTESOLV, was assumed to be about $0.20 \mathrm{ft}$ (table 3 ).

Before each slug test, the static water level at each well was measured with an electric water-level tape from the measuring point at the top of the casing using procedures specified by Cunningham and Schalk (2011) and recorded in the USGS NWIS database (U.S. Geological Survey, 2019). The static water-level measurement at each well was used to estimate aquifer saturated thickness. Additionally, the static water-level measurement was used to determine the depth to suspend the transducer below the water surface before completing the slug test and to determine the slug depth for full submergence during the slug test (table 3).

Slug tests were completed using techniques described by Cunningham and Schalk (2011) with a mechanical slug and a submersed pressure transducer. Several slug-in and slug-out test trials were completed at each well (table 4). At well SV1, one slug-in and one slug-out trial were completed, and at well SV2, two slug-in and three slug-out trials were completed. A Solinst Levelogger LT F30/M10 electronic transducer (unvented) was used to record water-level changes during each slug test. Transducer measurements are provided in the accompanying data release (Eldridge, 2020). The transducer was set to record the water levels at 0.5 -second intervals. The transducer depth was about $15 \mathrm{ft}$ below land surface to allow for adequate spacing in the well for the slug. Each slug-test trial used a 3-ft long, 1-in.-diameter mechanical slug that was constructed to the standards described by Cunningham and Schalk (2011). The slug was lowered quickly into the well to a depth about $1 \mathrm{ft}$ below the static water level. The water level was measured with an electric tape to ensure it stabilized, and then the slug was quickly removed.

Initial water-level response during slug insertion and removal at each well usually was oscillatory but generally stabilized in about $2-9$ seconds. Mechanical slugs were inserted quickly into the well, and the insertion likely caused some water-level oscillation during the start of the trial. The oscillation was corrected during analysis using techniques described by Butler (1998) and Pandit and Miner (1986). The correction required identifying the initial water displacement for each trial, the maximum water displacement for each trial, and a translation displacement (table 4). The translation displacement, or the first water level indicating nonoscillating behavior, was manually selected by plotting the water level in logarithmic scale and selecting the time of the water-level 


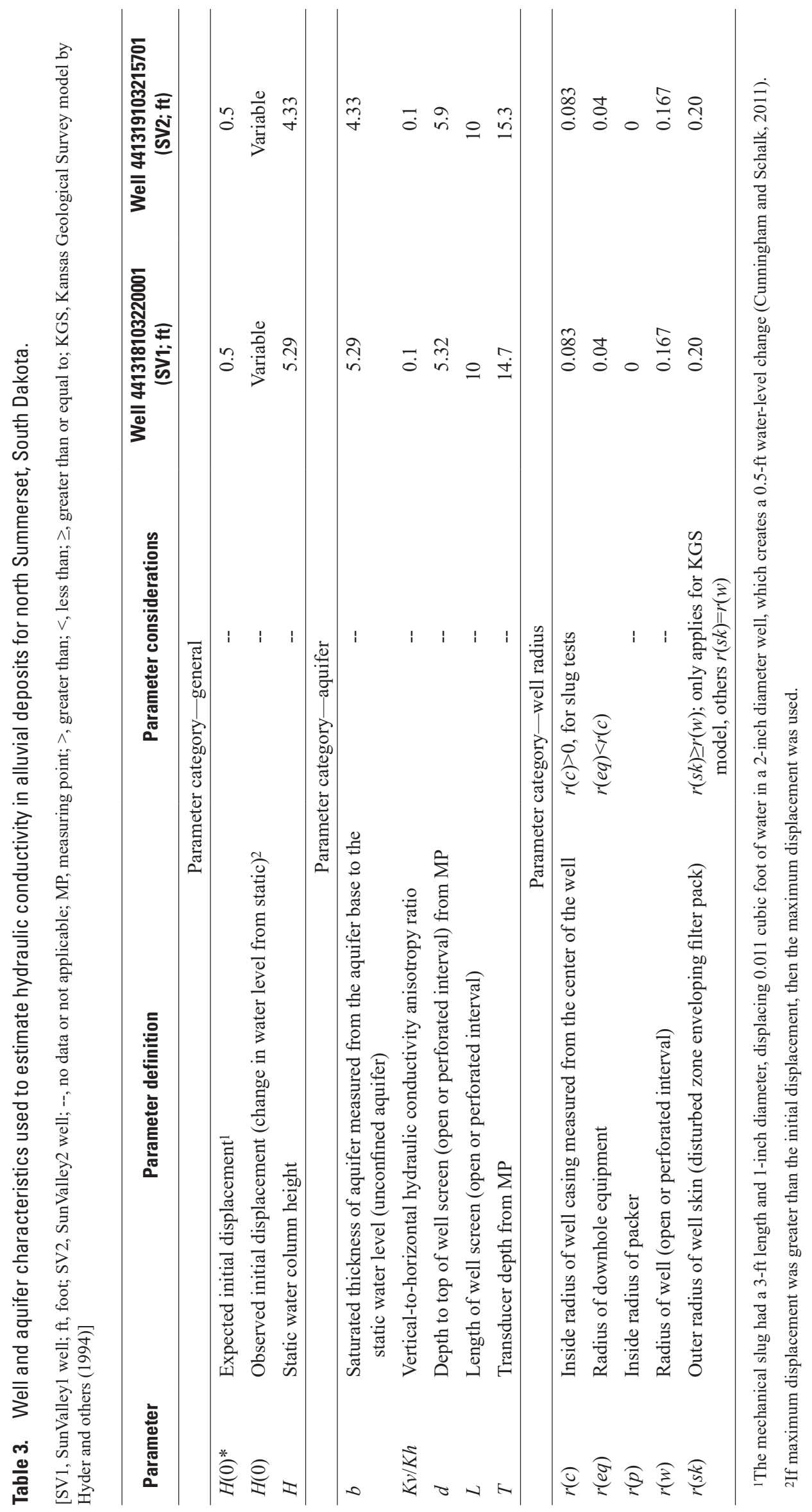


Table 4. Summary of slug-test results with estimated hydraulic conductivity, north Summerset, South Dakota.

[ft, foot; sec, second; K, hydraulic conductivity; ft/d, foot per day; NWIS, National Water Information System; SV1, SunValley1 well; SV2, SunValley2 well; --, method did not provide a solution]

\begin{tabular}{|c|c|c|c|c|c|c|c|}
\hline $\begin{array}{l}\text { Slug-test trial name } \\
\text { (Eldridge, 2020) }\end{array}$ & $\begin{array}{l}\text { Initial water } \\
\text { displacement } \\
\text { (ft) }\end{array}$ & $\begin{array}{c}\text { Maximum } \\
\text { water } \\
\text { displacement } \\
\text { (ft) }\end{array}$ & $\begin{array}{c}\text { Translation } \\
\text { displacement } \\
\text { (ft) }\end{array}$ & $\begin{array}{l}\text { Time } \\
\text { offset } \\
\text { (sec) }\end{array}$ & $\begin{array}{l}\text { Number } \\
\text { of data } \\
\text { points }\end{array}$ & $\begin{array}{c}\text { Test } \\
\text { duration } \\
\text { (sec) }\end{array}$ & $\begin{array}{c}\text { Bouwer-Rice method } \\
\text { (Bouwer and Rice, } \\
\text { 1976) solution within } \\
\text { hydraulic head range } \\
\text { (K, ft/d) }\end{array}$ \\
\hline \multicolumn{8}{|c|}{ NWIS well identifier 441318103220001 (SV1) $^{1}$} \\
\hline slugtestsv1_slugin 1 & 1.64 & 1.64 & 0.99 & 4.5 & 3,723 & 1,861 & 0.20 \\
\hline Mean & 1.17 & 1.53 & 1.00 & 4.8 & 2,877 & 1,438 & 0.23 \\
\hline Standard deviation & & & & & & & 0.03 \\
\hline \multicolumn{8}{|c|}{ NWIS well identifier $441319103215701(\mathrm{SV} 2)^{1}$} \\
\hline slugtestsv2_slugin 1 & 0.42 & 0.77 & 0.50 & 6 & 1,147 & 573 & 0.54 \\
\hline slugtestsv2_slugin2 & 1.02 & 1.02 & 0.41 & 4 & 855 & 427 & 1.1 \\
\hline Mean & 0.70 & 1.20 & 0.66 & 5 & 852 & 425 & 6.4 \\
\hline Standard deviation & & & & & & & 5.8 \\
\hline
\end{tabular}

${ }^{1}$ For all trials, the mean is $4.3 \mathrm{ft} / \mathrm{d}$, the median is $0.8 \mathrm{ft} / \mathrm{d}$, and the standard deviation is $5.6 \mathrm{ft} / \mathrm{d}$.

2 Trial did not produce a result because the water levels were not between the recommended normalized hydraulic head range for that trial for unknown reasons (Eldridge, 2020).

record (table 4). The selected time was the time offset applied to the data to exclude the oscillatory measurements. The time offset was equal to the time that the translation displacement water-level measurement was measured (table 4).

Water-level displacement for each trial was calculated by subtracting the raw transducer reading during each slug test from a datum water level. The datum water level for each trial was selected at a time shortly before the start of the slug test when the water level was stable. Transducer readings were raw, meaning that they were not corrected for barometric pressure, because only relative changes in water level, and not absolute values, were needed for analyses. Waterlevel data recorded during slug testing are available in the accompanying USGS data release (Eldridge, 2020), which includes slug-test trial number, time of water-level measurements, raw transducer readings, and water-level displacements from a zero datum. The maximum water-level displacement recorded by the transducer for each trial ranged from a high of $1.64 \mathrm{ft}$ at well SV1 to a low of $0.77 \mathrm{ft}$ at well SV2 (table 4). The expected water-level displacement was about $0.5 \mathrm{ft}$ (Cunningham and Schalk, 2011). The displacements exceeding $0.5 \mathrm{ft}$ likely were caused by water sloshing during slug insertion and removal.

Water-level changes for each trial were analyzed with AQTESOLV Pro version 4.50.002 (Hydrosolve, Inc., 2007; Eldridge, 2020) using the Bouwer-Rice method of curve fitting
(Bouwer and Rice, 1976). The Bouwer-Rice method determines hydraulic conductivity of unconfined aquifers by matching a straight-line curve to water levels collected during a slug test over time (AQTESOLV, 2020). The method assumes that the aquifer has infinite areal extent, is homogeneous, has uniform thickness, and has a horizontal potentiometric surface (initially); the well is fully or partially penetrating; the slug volume of water is injected or discharged instantaneously from the well; and the flow of water is steady (AQTESOLV, 2020). The assumptions were considered valid for the slug tests in the study because the aquifer boundary was more than $0.25 \mathrm{mi}$ from the slug-test locations, and the aquifer did not vary in thickness among the wells used for slug testing. Additionally, the potentiometric surface was assumed flat and flow was considered steady during the duration of the slug tests. Although the aquifer is not homogeneous, the length of the aquifer corresponding to the screen length of the wells used for slug testing was assumed homogeneous. Also, slugs were inserted quickly into the well to approximate instantaneous injection and discharge from the well; however, the difficulty in fully achieving instantaneous injection and discharge was the likely cause of inconsistent slug-test results among the slug-in and slug-out tests. Additionally, the aquifer anisotropy ratio $\left(K_{z} /\right.$ $K_{r}$ ratio in AQTESOLV, where $K_{z}$ is the vertical hydraulic conductivity and $K_{r}$ is the horizontal hydraulic conductivity) was assumed to be 0.1 for all trials because hydraulic conductivity 
in most geological formations indicates internal heterogeneous variations of one to two orders of magnitude (Freeze and Cherry, 1979).

AQTESOLV uses curve fitting to provide an estimate of hydraulic conductivity. The automatic curve-fitting feature in AQTESOLV usually was used; however, for some trials, the curve was manually adjusted to improve the fit. Manual adjustments were necessary when water levels were not linear when plotted on a logarithmic scale. Curve matching was simplified by applying normalized hydraulic head ranges to the curve matching plots (Duffield, 2020; Eldridge, 2020). The recommended normalized hydraulic head range for straightline matching was 0.2 to 0.3 for the Bouwer-Rice method. Using this range, a straight-line fit was easier to achieve because ambiguous data at the start and end of the slug test were not matched (Eldridge, 2020).

Hydraulic conductivity estimated from the AQTESOLV curve-fitting analysis using the Bouwer-Rice method for all slug-in and slug-out trials from the two observation wells in the study ranged from 0.20 to $0.26 \mathrm{ft} / \mathrm{d}$ for well 441318103220001 (SV1) and from 0.54 to $14 \mathrm{ft} / \mathrm{d}$ for well 441319103215701 (SV2; table 4). The mean, median, and standard deviation of all trials at both wells were $4.3 \mathrm{ft} / \mathrm{d}$, $0.8 \mathrm{ft} / \mathrm{d}$, and $5.6 \mathrm{ft} / \mathrm{d}$, respectively. The slug-test trial slugtestsv2 slugout1 at well 441319103215701 (SV2) did not produce a result because the water levels were not between the recommended normalized hydraulic head range for that trial for unknown reasons (Eldridge, 2020).

\section{Groundwater Flow}

A simple conceptual model of the groundwater-flow system of the alluvial aquifer in the area of interest near north Summerset, S. Dak., was developed and included the aquifer extent and dimensions, the direction of groundwater flow, recharge and evapotranspiration estimates, and an estimated water budget of inflows and outflows of groundwater (fig. 10). The alluvial aquifer extent was determined by geologic maps and lithologic logs. The groundwater-flow system was estimated using water-level records and topographic maps. Recharge and evapotranspiration were estimated from a SoilWater Balance (SWB) model developed by Westenbroek and others (2010). The groundwater budget was determined from inflow and outflow estimates of recharge, evapotranspiration, streamflow losses and gains to the alluvial aquifer, and boundary flows from adjacent aquifers.

\section{Aquifer Extent and Dimensions}

The alluvial aquifer extent and dimensions are affected by surrounding high terrain and streamflow. The alluvial aquifer extent is about $1 \mathrm{mi}$ in the north-south direction and about $1.5 \mathrm{mi}$ in the southeast-northwest direction in the area of interest (fig. 7). High terrain bounds the dimensions of the aquifer to the north, northeast, and southwest of the study area. The alluvium that composes the alluvial aquifer in the area of interest was transported and deposited to the low-elevation center of the study area near the Sun Valley Estates subdivision by past and current streams. The streamflow direction also is affected by the surrounding high terrain. The primary direction of streamflow is from the south and southwest, originating from the Paleozoic-age sedimentary deposits of limestones and shales on the east slope of the Black Hills (fig. 7). Streams flow from the south and southwest, pass through the study area, and then bend to the east and flow through a gap in the high terrain near the northeast boundary of the area of interest. The easterly bend in the stream network slows streamflow and causes sediments of gravel, sand, silt, and clay, or other rock material, to accumulate as alluvial deposits.

The thickness of the alluvial aquifer hydrogeologic unit (fig. 6) in the study area was determined from 31 lithologic logs and water-well completion reports from the South Dakota Geological Survey (South Dakota Geological Survey, 2018), the South Dakota Department of Environment and Natural Resources (South Dakota Department of Environment and Natural Resources, 2019), and the City of Summerset (Eldridge, 2020). The thickness of the alluvial deposits in the study area was estimated by determining the depth to the bottom of the alluvium from the land surface recorded in lithologic logs and water-well completion reports. Thicknesses from lithologic logs were plotted using the "XY Table to Point" tool and interpolated using the "Topo to Raster" tool from geographic information software (ArcGIS Pro; Esri, 2019; fig. 11). The "Topo to Raster" tool was designed specifically for creating surfaces using an iterative finite-difference interpolation method that combines the efficiency of local interpolation methods with the surface continuity of global interpolation methods (Esri, 2019). The interpolated map of alluvial deposit thickness was contoured using a 5-ft contour interval (fig. 11). Contour lines were manually edited to correct unrealistic thicknesses from areas of sparse data in the study area. Alluvium thicknesses ranged from 10 to $50 \mathrm{ft}$ in the study area. The thickest alluvial deposits in the southcentral part of the model area are shown in figure 11. Single points of high thickness ("bullseyes") were caused by the sparse lithologic logs and water-well completion reports available for interpolation. Additional lithologic information could smooth the interpolation and help eliminate bullseyes in the interpolation.

\section{Generalized Potentiometric-Surface and Groundwater-Flow Map}

Groundwater-flow conditions were determined using water levels measured in wells and described by hydrographs (a graph of water level with respect to time) and a generalized potentiometric-surface map. A potentiometric surface represents the hydraulic head of groundwater, which is the 


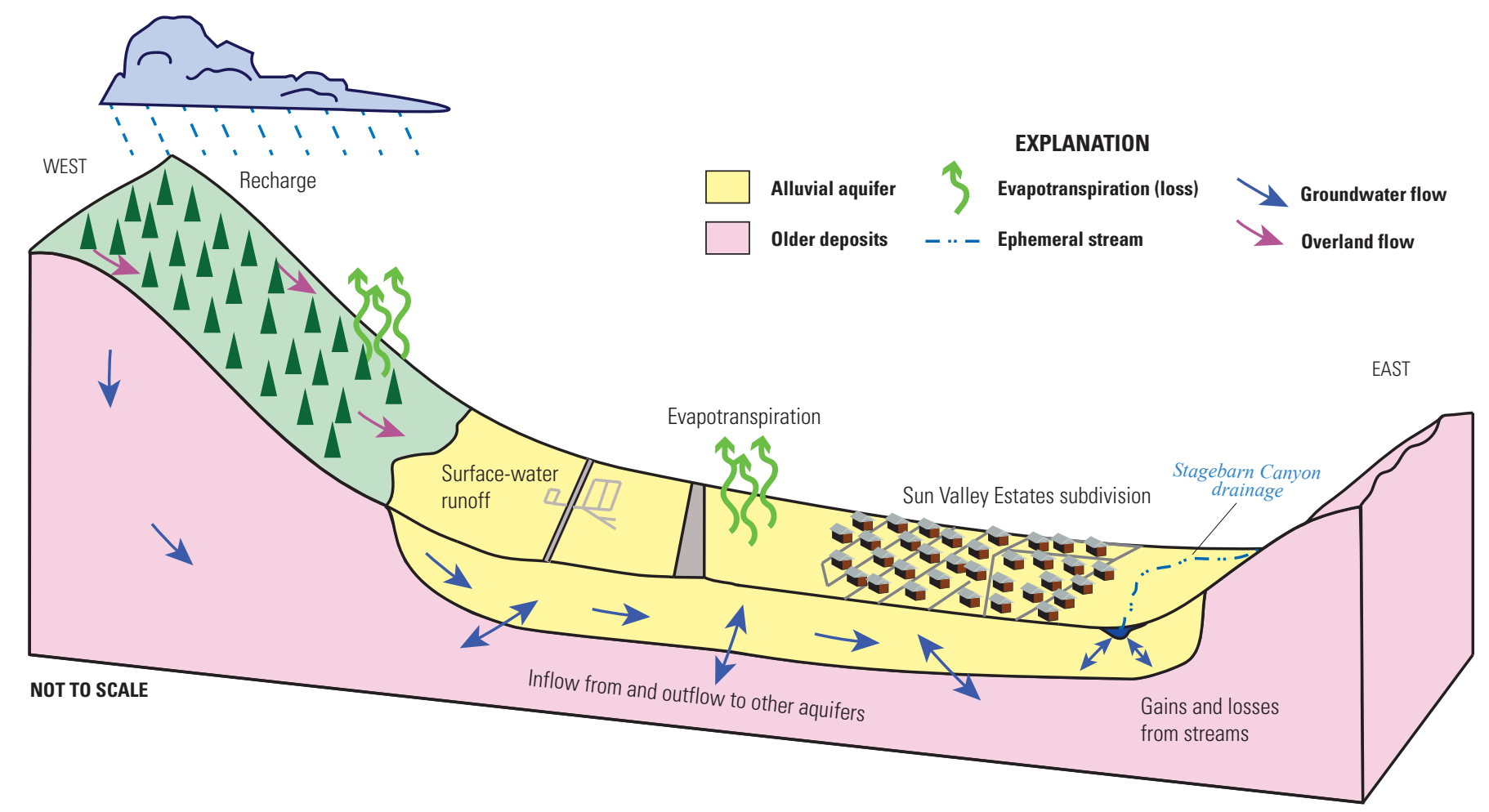

Figure 10. Simplified conceptual model of the alluvial aquifer in north Summerset, South Dakota.

water-table elevation in an unconfined aquifer (Carter and others, 2002). Potentiometric contours from the potentiometricsurface map were used to determine groundwater-flow direction, which was assumed to be perpendicular to the potentiometric contours. Groundwater-level elevations were reported in feet above the North American Vertical Datum of 1988 and are referred to as hydraulic head.

Hydrographs were constructed and compared for water levels from three observations wells at USGS sites 441318103220001 (SV1), 441319103215701 (SV2), and 441326103215101 (SunValley3 well [SV3]) in the Sun Valley Estates subdivision (fig. 1; fig. 12). Pressure transducers (Solinst Levelogger LT F15/M5) recorded hourly continuous observations at wells SV1 and SV2 beginning on July 3, 2019, and on August 6, 2019, respectively. Water levels in well SV2 decreased below the transducer on about August 24, 2019, and water levels were not recorded by the transducer after that date (fig. 12). The transducer in well SV3 failed shortly after installation and did not record water levels. In addition to continuous measurements from transducers, periodic water-level measurements were recorded for wells 441318103220001 (SV1), 441319103215701 (SV2), and 441326103215101 (SV3) starting on July 2, 2019, and ending December 31, 2019. All water-level measurements were cataloged in NWIS (U.S. Geological Survey, 2019). Water levels in all three wells generally followed similar trends - the highest water levels were in early July 2019 and steadily decreased through December 31, 2019 (fig. 12). Water levels in all three wells declined about $4.5 \mathrm{ft}$ from their respective peaks during the measurement period from early July through December 2019 (fig. 12).

Water-level data measured from wells completed in the alluvial aquifer in the study area were used to construct a potentiometric-surface map for the area of interest (fig. 13). Water-level measurements were available from only 5 wells in the study area (table 5), and the 5 wells had a total of 38 waterlevel measurements recorded from 1982 through 2019 in the USGS NWIS database (U.S. Geological Survey, 2019). Waterlevel measurements were recorded as depth below land surface and were converted to water-level elevations by subtracting the depth below land surface from the land-surface elevation at the well documented in NWIS (table 5). The maximum recorded hydraulic-head elevation was used for constructing the potentiometric-surface map for the area of interest to represent a worst case of the highest recorded water-levels in the aquifer.

Contours on the potentiometric-surface map were drawn manually using the maximum water-level elevations on record for each well and current land-surface contours in the area of interest. The potentiometric surface of the unconfined alluvial aquifer was assumed to follow the general contours of the land surface (fig. 13). Water levels in unconfined aquifers are commonly topographically controlled (Heath, 1983) and mirror land-surface elevation contours. Land-surface 


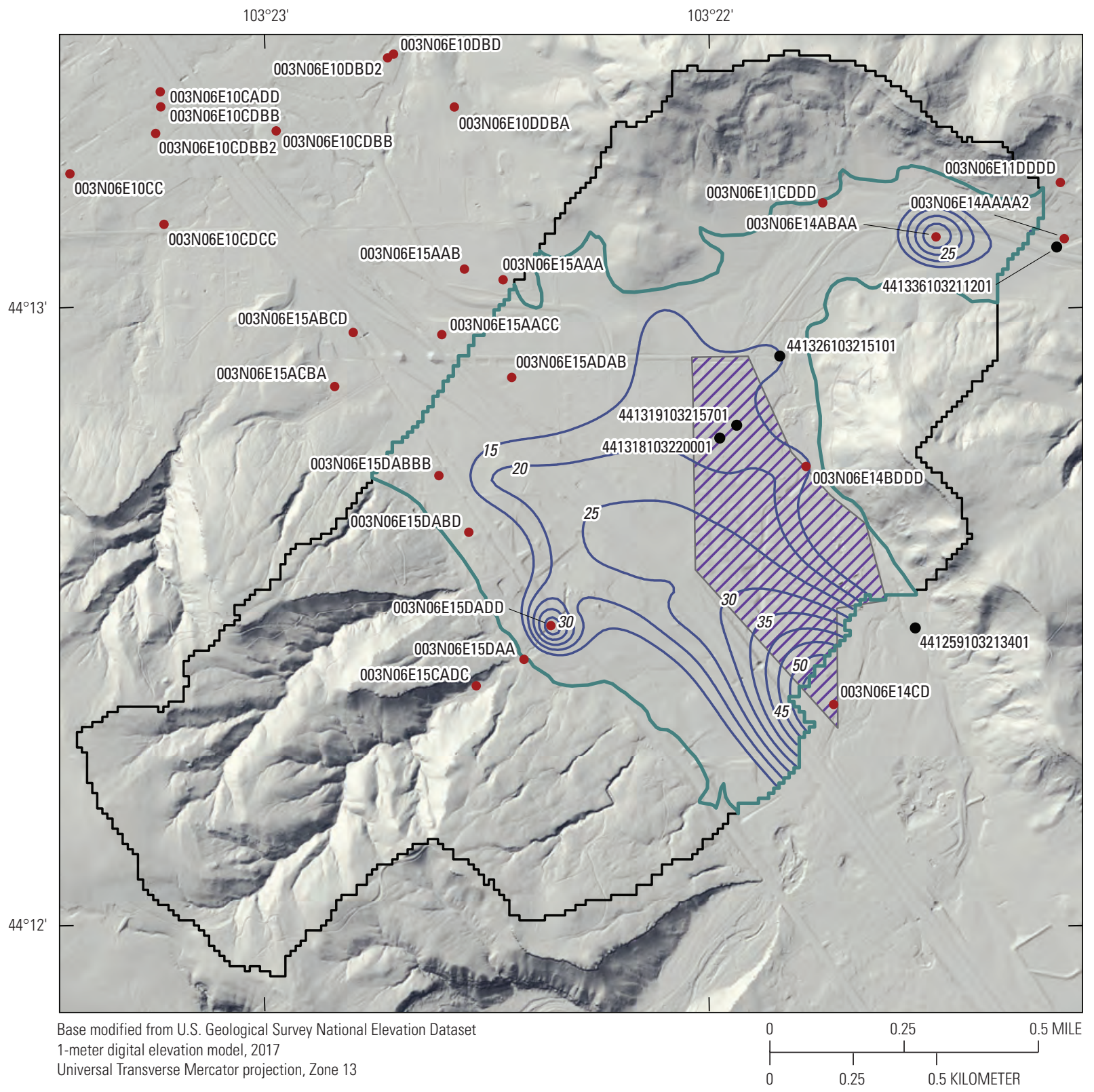

EXPLANATION

[SDDENR, South Dakota Department of Environment and Natural Resources; SDGS, South Dakota Geological Survey]

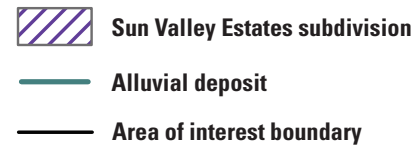

$$
\begin{gathered}
\text { Alluvium thickness contour-Shows thickness of } \\
\text { alluvial deposit, in feet. Contour interval } 5 \text { feet }
\end{gathered}
$$

Figure 11. Estimated alluvial deposit thickness in north Summerset, South Dakota. 


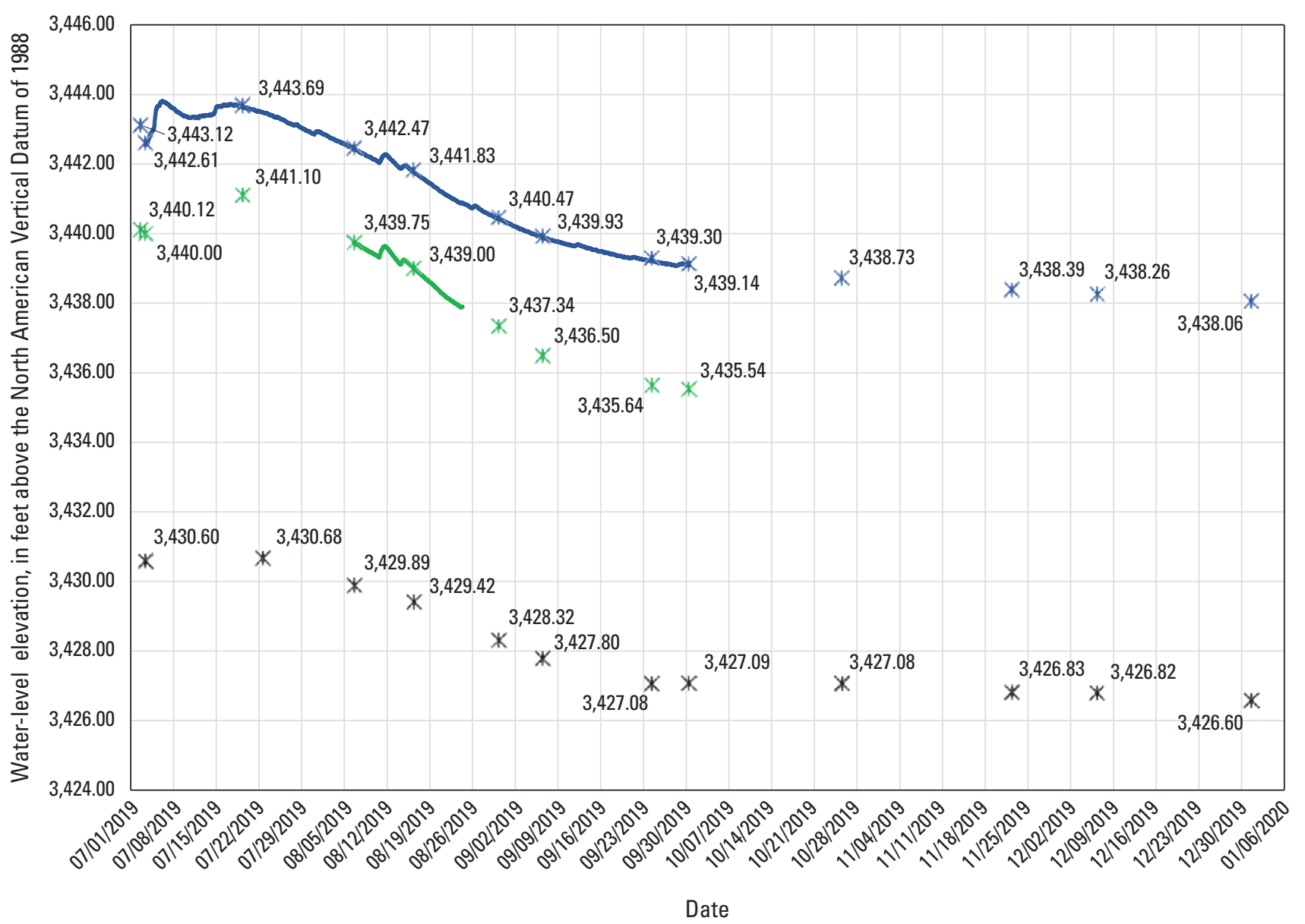

EXPLANATION

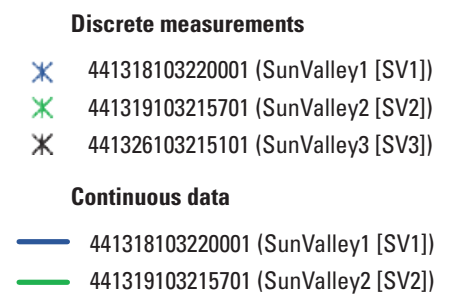

Figure 12. Hydrographs of U.S. Geological Survey wells 441318103220001 (SunValley1 [SV1]), 441319103215701 (SunValley2 [SV2]), and 441326103215101 (SunValley3 [SV3]) in north Summerset, South Dakota.

elevation contours were constructed at 10 -ft contour intervals from 1-meter digital elevation data (U.S. Geological Survey, 2017) using geographic information software (ArcGIS Pro; Esri, 2019).

The generalized potentiometric surface mapped for this study was used to estimate groundwater flow in the area of interest by drawing groundwater-flow paths in the alluvial aquifer perpendicular to the potentiometric contours (fig. 13). As shown in figure 13, groundwater in the alluvial aquifer under the Sun Valley Estates subdivision originates from higher elevations of the southwest part of the area of interest and from streams in the southeast part of the map. Groundwater flows from the southwest to the northeast and exits the area of interest to the east (fig. 13). The hydraulic gradient is highest where the potentiometric lines are close together, which is in the southwest part of the area of interest (fig. 13). Relatively higher gradients indicate relatively higher groundwater-flow rates. The gradient becomes lower as the terrain flattens in the northeast part of the alluvial aquifer in the area of interest (fig. 13). Lower gradients indicate slower groundwater movement and flow rates. The groundwater-flow direction in the southeast part of the area of interest is toward the streams and nearly parallel to the Stagebarn Canyon drainage (fig. 1). The groundwater-flow path towards the streams indicates that the streams may receive groundwater from the alluvial aquifer when the water-level elevation in the aquifer is higher than the stream bed elevation. 


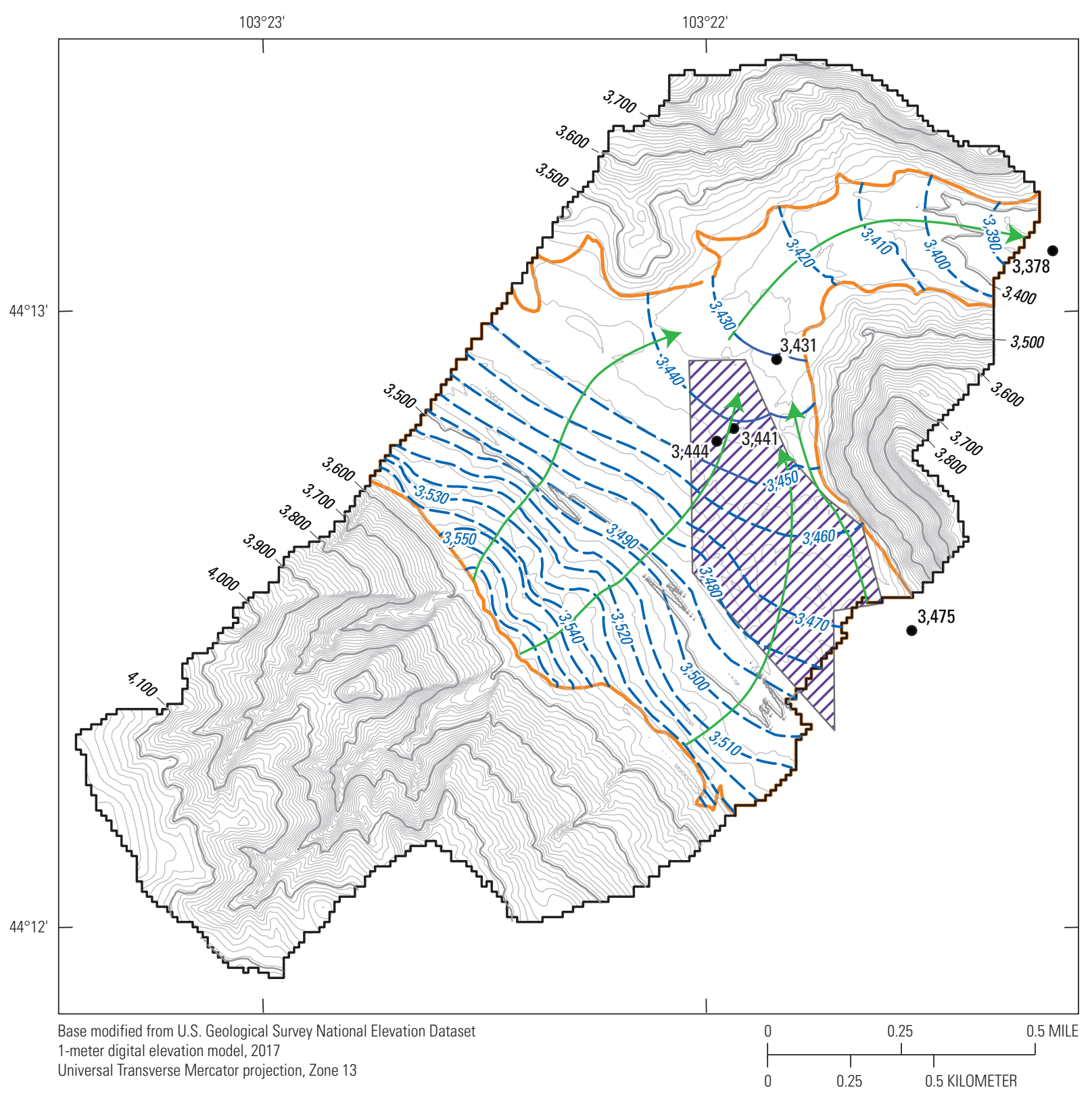

EXPLANATION
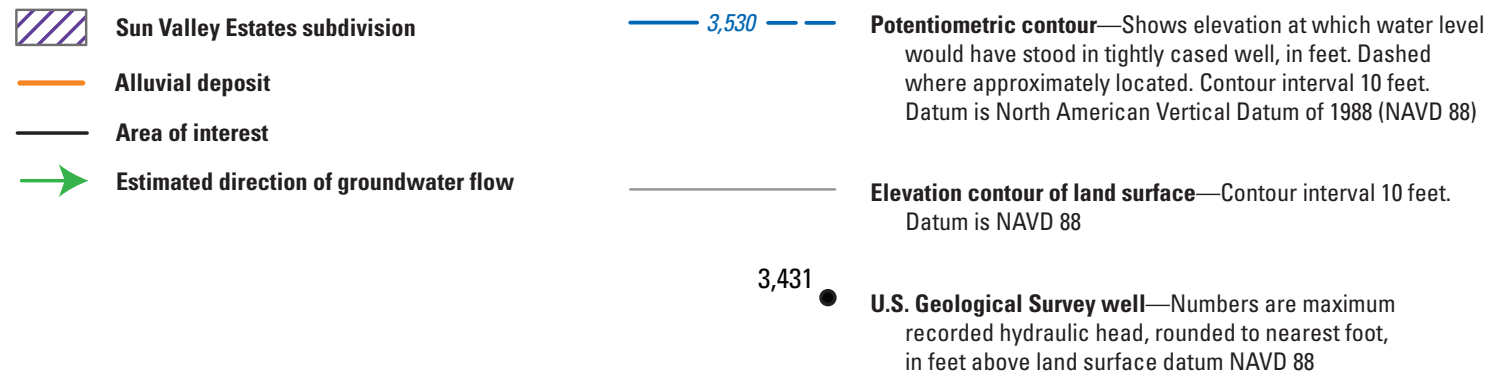

Figure 13. Generalized potentiometric-surface map of alluvial deposits in north Summerset, South Dakota, using the maximum water-level elevation on record and land-surface contours. 


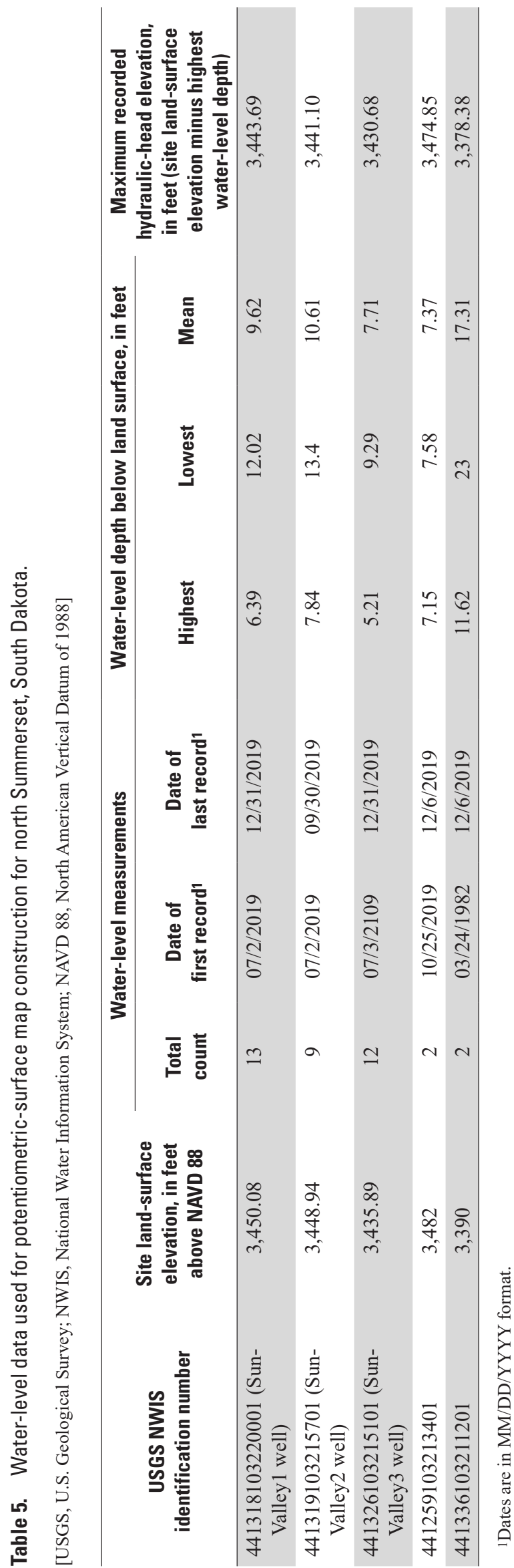




\section{Sources and Estimates of Recharge and Discharge in the Study Area}

The sources of recharge and discharge for the alluvial aquifer in the study area were assumed primarily to be precipitation and evapotranspiration, respectively. Recharge and potential evapotranspiration were estimated using an SWB model (Westenbroek and others, 2010) for calendar years 2017-19. Potential evapotranspiration is the amount of water that can be removed from the saturated groundwater by evapotranspiration if there is no deficiency of water in the soil for use by vegetation (Wilson and Moore, 1998).

The SWB model calculates recharge separately in each model grid cell using a modified Thornthwaite-Mather soilwater accounting method (Thornthwaite and Mather, 1957). The SWB model requires inputs of tabular daily climate data and gridded spatial data (Westenbroek and others, 2010). The study area was discretized for the SWB model into 202 columns and 191 rows of square cells with side lengths of $50 \mathrm{ft}$. Daily climate data tabulated for entry into the SWB included precipitation, maximum temperature, and minimum temperature. The accompanying data release includes the daily tabulated climate data (Eldridge, 2020). Daily precipitation values were calculated by inverse-distance weighting daily precipitation measurements from four NOAA climate stations (National Oceanic and Atmospheric Administration, 2019b) near the study area (fig. 1). Daily minimum and maximum temperatures near the study area were available only from NOAA site USC00396947 (Rapid City 4 NW, SD US; National Oceanic and Atmospheric Administration, 2019b) for 2017-19 and were used for the SWB model. Gridded spatial data included land-cover type, hydrologic soil group, available soil-water capacity, and surface-water-flow direction and were transformed from resampled raster data into the American Standard Code for Information Interchange file format.

Land-cover type data for the SWB model were obtained from the 2016 National Land Cover Database (Yang and others, 2018). Land-cover type data were projected, resampled to the SWB model cell size, and clipped to the study area using methods described by Tillman (2015). The land-cover grid used for the SWB model is available in the accompanying data release (Eldridge, 2020).

Hydrologic soil group data were obtained from the U.S. Department of Agriculture Geospatial Data Gateway (U.S. Department of Agriculture, 2018). Hydrologic soil group data were prepared with 10-meter resolution Gridded Soil Survey Geographic (gSSURGO) soils data from the U.S. Department of Agriculture Natural Resources Conservation Service (U.S. Department of Agriculture, 2014). The Natural Resources Conservation Service defines four categories of hydrologic soil groups ranging from group A (high infiltration rate) to group D (low infiltration rate; U.S. Department of Agriculture, 2009). Methods described in the gSSURGO User Guide (U.S. Department of Agriculture, 2014) and Tillman (2015) were used to link hydrologic soil groups to the 10-meter gSSURGO raster cells identified by a map unit key. Null (missing) data values (-99999) were replaced with the primary soil type of neighboring cells. The hydrologic soil group grid used by the SWB model is available in the accompanying data release (Eldridge, 2020).

Available soil-water capacity data also were obtained from the U.S. Department of Agriculture Geospatial Data Gateway (U.S. Department of Agriculture, 2018). Available soil-water capacity data were prepared like the hydrologic soil group data. The 10-meter resolution gSSURGO data were linked, using each raster map unit key, to attributes for two datasets: (1) available water storage in the total soil profile from the surface to the depth of the soil profile (AWS0_999) and (2) the thickness of soil components used in the total soil profile (tk0_999a). The available water content was calculated for each model cell by dividing AWS0_999 by tk0_999a and multiplying by a unit conversion factor of 1.19787 to convert from millimeters per centimeter to inches per foot. Values are required for every cell in the SWB model; therefore, cells with null (missing) data (-99999) after the conversion were replaced with zero. The available soil-water capacity grid used by the SWB model is available in the accompanying data release (Eldridge, 2020).

The general surface-water-flow direction input file for the model area was constructed for use in the SWB model to route surface-water flow (from rejected recharge) in model cells to adjacent model cells. Methods described by Tillman (2015) were used to project and resample a 1-meter digital elevation model (U.S. Geological Survey, 2017) to match the model projection and grid size and to construct an American Standard Code for Information Interchange file containing a grid of surface-water-flow direction for each model cell. The general surface-water-flow direction grid used by the SWB model is available in the accompanying data release (Eldridge, 2020).

The SWB model also required several control variables and parameters specified in the model control file (Eldridge, 2020) and defined by Westenbroek and others (2010). The growing season was set to 124 days between the 137 th (May 17) and 261st (September 8) days of the year based on the mean start and end day of the 50-percent freeze probability curve for Hill City, Hot Springs, Rapid City Airport, Spearfish, and Mount Rushmore, S. Dak. (Koss and others, 1988; South Dakota State University, 2014). Initial soil moisture was set to 50 -percent saturation as an estimated starting condition. Initial abstraction was set to the Hawkins method, which increases runoff of small precipitation events (Westenbroek and others, 2010) and was appropriate for the model area because it contained about 18 percent of developed land. The initial frozen ground index was set to 100, assuming frozen ground at the SWB model start time of January 1, and the upper and lower continuous frozen ground threshold values were set to 83 and 56, respectively, as recommended by Westenbroek and others (2010). Initial snow cover was set to 0.2 water equivalent (inches of water), simulating an estimated 2 in. of snow cover in the study area at the SWB model start time of January 1 . The runoff method was set to downhill, which is a faster model execution method for routing surface-water flow 
(Westenbroek and others, 2010). The Hargreaves and Samani (1985) option was specified as the SWB model evaporation method between 43.2 and 45.0 degrees north latitude, corresponding to the north and south study area boundaries. The Hargreaves and Samani (1985) option was used because only the daily minimum, maximum, and mean temperature and precipitation were available in the SWB model (Westenbroek and others, 2010).

A lookup table of tabular information is another required input for the SWB model. The lookup table consists of runoff curve numbers, maximum daily infiltration rates, and root depths for each pair of the 4 hydrologic soil groups and 12 land-cover types. The lookup table also consists of assumed impervious values and interception storage values; however, both values are paired only with land-cover types and not the hydrologic soil groups. Assumed impervious percentage values were determined from Westenbroek and others (2010). Interception storage values were determined from Westenbroek and others (2010) and Tillman (2015). The curve numbers, which are indicators of relative runoff potential, for each hydrologic soil group were obtained from the Natural Resources Conservation Service Hydrology Handbook (U.S. Department of Agriculture, 2004), Westenbroek and others (2010), and Tillman (2015). Maximum daily infiltration rates, used by the SWB model to set a maximum recharge for each model cell, were also assigned based on values reported by Westenbroek and others (2010) and Tillman (2015). Root zone depth, used by the SWB model to determine the maximum soil-water capacity for a model cell, for each soil type were from Canadell and others (1996), Westenbroek and others (2010), and Tillman (2015). The lookup table is provided in the accompanying data release (Eldridge, 2020).

The matrix of annual mean recharge for each model cell and potential evapotranspiration for 2019 estimated by the SWB model were mapped in the study area (fig. 14). The recharge for 2019 had values ranging from 0 to $11.4 \mathrm{in}$. and an annual mean of $5.1 \mathrm{in.}$ across the study area. The map also shows higher total recharge in alluvial deposits near the Sun Valley Estates subdivision and along streams (fig. 14). Lower total recharge values were in high elevation areas in the east part of the study area and at the base of high elevations in the southwest part of the study area (fig. 14). Potential evapotranspiration estimated by the SWB model for 2019 were mapped as straight contour lines because the estimate was based on latitude and climate data in the study area. Potential evapotranspiration contours ranged from 28.90 to $28.75 \mathrm{in}$. and the annual mean was 28.86 in. across the study area (fig. 14; Eldridge, 2020).

\section{Estimated Groundwater Budget Components}

Groundwater budget components were estimated for the alluvial aquifer in the area of interest for 2019. Groundwater budget components included inflows and outflows (fig. 10). Inflow sources were recharge from precipitation, streamflow, and inflows from exchanges with adjacent aquifers along the boundaries of the alluvial aquifer. Outflow sources were actual evapotranspiration, outflows to streams, and outflows from exchanges with adjacent hydraulically connected aquifers. The change in aquifer storage was assumed to be zero from the start of 2019 to the end of 2019 and was not included as a budget component. Additionally, groundwater flow to and from the underlying undifferentiated units was assumed to be negligible and not included as a budget component. The methods used to estimate each budget component are explained in the following paragraphs.

The rate and total volume of recharge from precipitation to the alluvial aquifer in the area of interest in 2019 were estimated from the SWB model results (Eldridge, 2020). Simulated recharge estimates from 2019 from the SWB model were clipped to the extent of the alluvial deposits in the area of interest and converted to a total volume by multiplying the recharge estimate for each model cell by the surface area of the cell $\left(2,500\right.$ square feet [ $\left.\left.\mathrm{ft}^{2}\right]\right)$. The volumes from all cells were summed to calculate the total volume of water recharged to the alluvial aquifer within the extent of the alluvial deposits in the area of interest. The result was about 70 million gallons (Mgal) of precipitation recharge to the alluvial aquifer in the area of interest for 2019 or a rate of about 0.3 cubic foot per second $\left(\mathrm{ft}^{\mathrm{t}} 3 \mathrm{~s}\right)$.

Inflow from streams to the alluvial aquifer in the area of interest in 2019 was estimated from discharges recorded by the Summerset water reclamation facility (fig. 1). The Summerset water reclamation facility discharges reclaimed water into the Stagebarn Canyon drainage near the southeast part of the area of interest (fig. 1). Inflow data to the Summerset water reclamation facility were available from March 19, 2019, through February 20, 2020 (table 6). Inflows to the Summerset water reclamation facility increased to greater than normal in June, July, and August 2019 because groundwater flowed into sewer accesses near manholes. Groundwater flowed into the sewer system through maintenance access points and then flowed through the water reclamation facility until it was discharged into the Stagebarn Canyon drainage. Discharge into the Stagebarn Canyon drainage was assumed to equal inflow to the Summerset water reclamation facility.

The 2019 groundwater budget value for inflows from streamflow was calculated from Summerset water reclamation facility inflow from March through December 2019. Data from January and February 2020 were substituted for missing data in January and February 2019. Streamflow losses from Stagebarn Canyon drainage to the alluvial aquifer in the area of interest were estimated using streamflow differences crudely measured using a flume (Turnipseed and Sauer, 2010) on December 5, 2019. A flume was used because the discharge of Stagebarn Canyon drainage was less than $0.5 \mathrm{ft} 3 / \mathrm{s}$, and the use of a flow meter would be impractical to measure the streamflow. Two discharge measurements were made on December 5, 2019, along the Stagebarn Canyon drainage within about 60 minutes. The upstream measurement was at the east boundary of the area of interest, and the downstream 


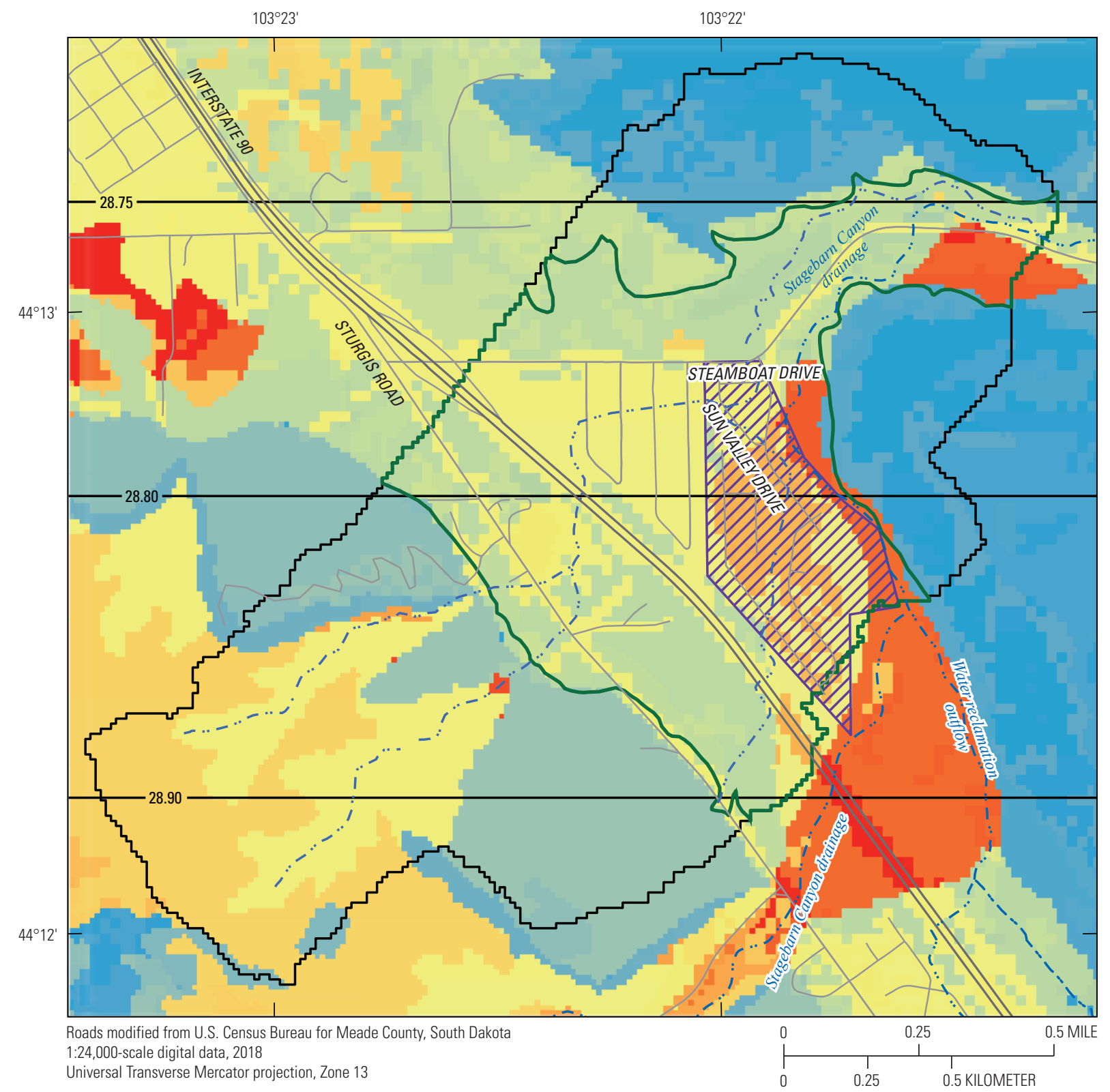

EXPLANATION

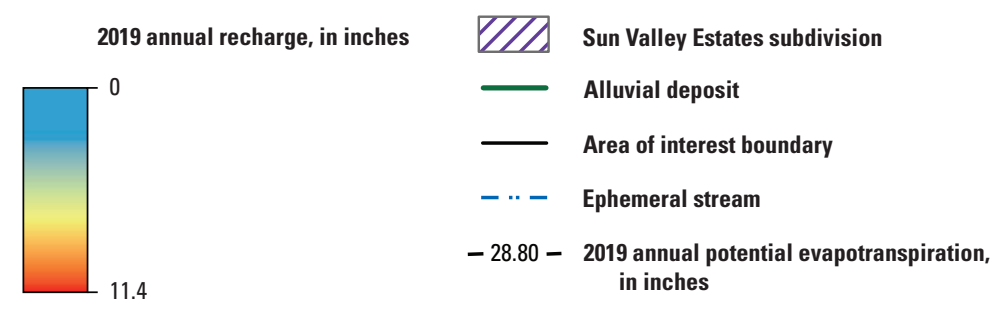

Figure 14. Soil-Water Balance-modeled spatial distribution of recharge and contours of potential evapotranspiration for 2019 (Eldridge, 2020), north Summerset, South Dakota. 
Table 6. Inflows into Summerset water reclamation facility and estimates of discharge to Stagebarn Canyon drainage with streamflow losses to the alluvial aquifer for north Summerset, South Dakota.

[Data from Tanner Fenenga, Summerset Public Works, written commun., March 2, 2020. Mean daily rate, 187,300 gallons per day, 130 gallons per minute, 0.29 cubic foot per second; mean estimated streamflow loss to alluvial aquifer, 0.15 cubic foot per second; gal, gallon; ft3/s, cubic foot per second; --, no data or not applicable]

\begin{tabular}{ccccc}
\hline $\begin{array}{c}\text { Measurement date } \\
\text { (MM/DD/YYYY) }\end{array}$ & $\begin{array}{c}\text { Number of days } \\
\text { between measurements }\end{array}$ & $\begin{array}{c}\text { Total inflow into Summerset } \\
\text { water treatment facility (gal) }\end{array}$ & $\begin{array}{c}\text { Discharge to water recla- } \\
\text { mation outflow (ft } \mathbf{s} / \mathbf{s})\end{array}$ & $\begin{array}{c}\text { Estimated streamflow loss } \\
\text { to alluvial aquifer (ft } 3 / \mathbf{s})\end{array}$ \\
\hline $03 / 19 / 2019$ & 30 & $4,915,000$ & 0.25 & 0.13 \\
$04 / 19 / 2019$ & 31 & $4,459,000$ & 0.22 & 0.11 \\
$05 / 19 / 2019$ & 30 & $5,136,000$ & 0.26 & 0.13 \\
$06 / 19 / 2019$ & 31 & $8,827,000$ & 0.44 & 0.22 \\
$07 / 19 / 2019$ & 30 & $8,416,000$ & 0.43 & 0.22 \\
$08 / 19 / 2019$ & 31 & $6,431,000$ & 0.32 & 0.16 \\
$09 / 19 / 2019$ & 31 & $5,239,000$ & 0.26 & 0.13 \\
$10 / 19 / 2019$ & 30 & $5,666,000$ & 0.29 & 0.15 \\
$11 / 19 / 2019$ & 31 & $5,338,000$ & 0.27 & 0.13 \\
$12 / 19 / 2019$ & 30 & $5,150,000$ & 0.27 & 0.13 \\
$01 / 20 / 2020$ & 32 & $4,775,000$ & 0.23 & 0.12 \\
$02 / 20 / 2020$ & 31 & $4,592,000$ & 0.23 & 0.11 \\
Total & 368 & $68,944,000$ & -- & - \\
\hline
\end{tabular}

measurement was near the point at which the Stagebarn Canyon drainage flows out of the area of interest to the east. The upstream discharge was $0.345 \mathrm{ft} 3 / \mathrm{s}$ (stream stage of $0.47 \mathrm{ft}$ ), and the downstream discharge was $0.170 \mathrm{ft} 3 / \mathrm{s}$ (stream stage of $0.31 \mathrm{ft}$ ). Streamflow loss between the upstream and downstream measurements was $0.166 \mathrm{ft} 3 / \mathrm{s}$ (48.1 percent), and the stream stage decrease was $0.16 \mathrm{ft}$. The measurements indicated that on December 5, 2019, the Stagebarn Canyon drainage was losing about one-half of its streamflow to the alluvial aquifer along the reach from the water reclamation facility to about the northeast boundary of the area of interest. Estimates for the groundwater budget assumed that (1) the mean annual rate of inflow to the aquifer from streamflow along the Stagebarn Canyon drainage was about 50 percent of the mean discharge to the Stagebarn Canyon drainage from the Summerset water reclamation facility, and (2) the mean daily discharge to the water reclamation outflow was $0.29 \mathrm{ft} 3 / \mathrm{s}$ for 2019 with only small seasonal variation ranging from 0 to $0.15 \mathrm{ft}^{3} / \mathrm{s}$ (table 6 ). The mean estimated streamflow loss to the alluvial aquifer in the area of interest was about $0.15 \mathrm{ft}^{3} / \mathrm{s}$ in 2019 (table 6); the value was rounded to $0.2 \mathrm{ft} 3 / \mathrm{s}$ and used as an estimate for inflow from streams in the groundwater budget for 2019 (table 7).

Inflow and outflow from hydraulically connected aquifers to the alluvial aquifer were calculated using Darcy's law, which can be used to calculate the quantity of water moving through a unit area of an aquifer (Heath, 1983). Darcy's law is shown in equation 1 :

$$
Q=K A\left(\frac{d h}{d l}\right)
$$

where

$$
\begin{aligned}
& Q \quad \text { is quantity of water per unit of time; } \\
& K \quad \text { is the hydraulic conductivity; } \\
& A \text { is the cross-sectional area, at a right angle to } \\
& \text { the flow direction; and } \\
& d h / d l \quad \text { is the hydraulic gradient, or head loss per unit } \\
& \text { distance. }
\end{aligned}
$$

The following numerical values were used in equation 1 to calculate values for the inflows and outflows at the groundwater-flow boundaries of the alluvial aquifer: the $K$ variable was set to $0.8 \mathrm{ft} / \mathrm{d}$ (median value of $K$ in table 4); the $A$ variable was set to $51,350 \mathrm{ft}^{2}$ and $5,300 \mathrm{ft}^{2}$ for the southeast groundwater inflow boundary and northeast groundwater outflow boundary of the area of interest, respectively; $d h / d l$ was estimated as 0.0076 foot per foot $(\mathrm{ft} / \mathrm{ft})$ and $0.010 \mathrm{ft} / \mathrm{ft}$ at the southeast groundwater inflow boundary and northeast groundwater outflow boundary of the area of interest, respectively; and $Q$ was calculated as an inflow of 310 cubic feet per day ( $\mathrm{ft} 3 / \mathrm{d}$; $0.9 \mathrm{Mgal}$ for 2019) in the southeast area of interest and as an outflow of $42 \mathrm{ft} 3 / \mathrm{d}$ (0.1 Mgal for 2019) in the northeast area of interest. Calculated $Q$ values were rounded and included in the groundwater budget for 2019 as inflow from adjacent aquifers and outflow to adjacent aquifers (table 7).

Other groundwater budget terms included outflows to evapotranspiration and streams. Outflow to evapotranspiration was calculated by assuming that all groundwater budget inflows equaled outflows. The outflow to other aquifers was 
Table 7. Estimated groundwater budget components for the alluvial aquifer of north Summerset, South Dakota, 2019.

[ft $\mathrm{ft}^{3} / \mathrm{s}$, cubic foot per second; $\mathrm{ft}^{3} / \mathrm{d}$, cubic foot per day; Mgal, millions of gallons; $<$, less than; --, not applicable or no value]

\begin{tabular}{|c|c|c|c|c|}
\hline Budget component & Rate $\left(\mathrm{ft}^{3} / \mathrm{s}\right)$ & Rate $\left(\mathrm{ft}^{3} / \mathrm{d}\right)$ & Volume in 2019 (Mgal)'1 & $\begin{array}{l}\text { Percentage of total } \\
\text { flow type }\end{array}$ \\
\hline \multicolumn{5}{|c|}{ Inflow to aquifer } \\
\hline Recharge from precipitation & 0.3 & 26,000 & 70 & 66 \\
\hline From streams & 0.2 & 13,000 & 34 & 33 \\
\hline Inflow from adjacent aquifers & 0.003 & 300 & 0.9 & $<1$ \\
\hline Total inflows & 0.5 & 39,300 & 105 & 100 \\
\hline \multicolumn{5}{|c|}{ Outflow from aquifer } \\
\hline Evapotranspiration & 0.5 & 39,260 & 105 & 99 \\
\hline To streams & -- & -- & -- & -- \\
\hline Outflow to adjacent aquifers & 0.0005 & 40 & 0.1 & $<1$ \\
\hline Total outflows & 0.5 & 39,300 & 105 & 100 \\
\hline
\end{tabular}

${ }^{1}$ Values are rounded and may not exactly add to total value.

subtracted from the total of all inflows, resulting in an estimated outflow to evapotranspiration of $0.5 \mathrm{ft} 3 / \mathrm{s}$ for 2019 . Outflow to streams was assumed to be zero because the streams in the area of interest are ephemeral and receive water from mostly runoff after rains or from inflow sources such as the Summerset water reclamation facility. Total estimated groundwater budget components for inflows for 2019 were about 66 percent from recharge, 33 percent from stream discharge, and 1 percent from inflow from adjacent aquifers. Total estimated outflows were about 99-percent evapotranspiration and less than 1-percent outflow to adjacent aquifers (table 7).

\section{Data and Interpretive Limitations}

The data and methods of data interpretation had several limitations that could affect the accuracy of the hydrogeologic characterization of the study area. Limitations included (1) the few sources of data for water levels, lithology, and climate data available in the study area; (2) the interpretive curvefitting methods used for calculating hydraulic conductivity from slug-test data; (3) the assumptions for the SWB model; and (4) the estimates used for budget calculation.

Water-level, lithology, and climate datasets were limited in the study area. Areas lacking data potentially create regions in contour maps with less accurate interpolation and (or) highly inferred contours. Only five wells in the study area had water-level data. Water-level contours of the potentiometric map were assumed to mimic terrain contours, but additional water-level measurements in the study area could have validated the assumption. Taylor and Alley (2001) highlighted the importance of long-term groundwater-level monitoring and the effects of data gaps when spatially interpolating water-level data. Although 31 lithologic logs from wells were available in the study area, only 10 of the 31 were completed in the alluvial deposits in the area of interest; therefore, the saturated thickness of $0.7 \mathrm{mi}^{2}$ of the alluvial aquifer in the area of interest was estimated from only 10 wells. The lack of lithologic information created inaccuracies in interpolated aquifer thickness for parts of the aquifer far away from wells. Additionally, the lack of lithologic data caused the interpolation method to create "bullseyes" in the thickness map at well sites with lithologic information. Another data limitation affecting aquifer thickness accuracy was that the depth to the bottom of the alluvial deposits was not specified on every lithologic well $\log$. The assumption that the bottom of the well corresponded to the bottom of the alluvial deposits could have resulted in underestimating the depth of the aquifer at the location of those wells. Climate data, such as daily precipitation and daily temperature, were not available in the study area because the study area did not have a climate station. Precipitation and temperature data were interpolated from surrounding climate stations, and the resulting estimates, which were used to determine recharge and evapotranspiration, may not have accurately represented climate conditions in the study area, causing inaccuracies in the recharge and evapotranspiration estimates.

The curve-fitting interpretive methods used to estimate hydraulic conductivity from slug-test data relied on subjective decisions and on several assumptions. The Bouwer and Rice (1976) method required automatic and manual curve fitting within recommended hydraulic head ranges to estimate hydraulic conductivity. Manual curve fitting is subjective and can produce variations in outcomes when performed repeatedly for the same water-level change data. A single trial for well 441319103215701 (SV2) did not provide results using the Bouwer and Rice (1976) method because a linear best-fit line could not be plotted for its water-level response within the recommended hydraulic head ranges. The failed trial reduced the number of trials used to estimate the mean hydraulic 
conductivity of the alluvial aquifer. Additionally, some of the assumptions (AQTESOLV, 2020) of the Bouwer-Rice method (Bouwer and Rice, 1976) were not fully met. If the assumption that the aquifer was homogeneous over the screened interval of the well was incorrect, then the hydraulic conductivity calculations for the alluvial aquifer could be over or underestimated.

The SWB model version used for this analysis had limitations and assumptions outlined in its documentation (Westenbroek and others, 2010). One limitation applicable to this study was the tendency of the runoff routing option to cause high values of recharge in a few model cells. This model limitation could cause overestimates of recharge, which could affect the accuracy of the estimated water budget components. Additionally, the SWB model is sensitive to snowmelt inputs (Westenbroek and others, 2010), and snowfall and snowmelt are climate features common in the study area. Snowmelt in the SWB model is affected by the continuous frozen ground threshold values, which define the boundaries between completely frozen soil and unfrozen soil, expressed in degreeCelsius days. The values were set based on recommendations by Westenbroek and others (2010), but inaccuracies in the values could result in under or overestimating recharge.

The groundwater budget estimates for the alluvial aquifer in north Summerset also had limitations. Inflows to the alluvial aquifer from streamflow were estimated from city records from the Summerset water reclamation facility and only two field estimates of stream discharge at two locations. These estimates were assumed to be static for the entire year of 2019; however, stream and other surface-water contributions to the groundwater in the alluvial aquifer likely vary throughout the year in the study area. The result of this limitation is inaccuracy of the groundwater budget components for the alluvial aquifer. Additionally, aquifer storage change was assumed to be zero from the beginning to the end of 2019. If groundwater storage had increased in 2019, then actual evapotranspiration was overestimated for 2019. Periodic discharge measurements along the stream reaches in the study area could increase the accuracy of the groundwater budget terms, and annual waterlevel measurement in the alluvial aquifer could verify the assumption that storage changes are zero during a year.

\section{Summary}

The city of Summerset is a growing community in west South Dakota. The Sun Valley Estates subdivision in the north part of the city was developed on unconsolidated deposits surrounded by steep terrain. During years with greater than normal precipitation, particularly in 2019, groundwater levels increased in the unconsolidated deposits and caused damage to stormwater systems, sewer infrastructure, and houses with basements. The U.S. Geological Survey, in cooperation with the City of Summerset, completed a study of the hydrogeology and groundwater flow in the alluvial aquifer part of the unconsolidated deposits in north Summerset to understand the groundwater system in the area and to provide hydrogeologic information in support of future development planning.

The study area included most of the Sun Valley Estates subdivision in the north part of the city of Summerset in the east Black Hills of west South Dakota. About 0.7 square mile of water-bearing alluvial deposits is included in the study area. The contributing watershed defined by a delineation point on the northeast boundary of the area of interest and along the Stagebarn Canyon drainage is about 24.1 square miles and ranges from about 0.5 mile north of the Sun Valley Estates subdivision to about 4 miles east into the east foothills of the Black Hills. Daily precipitation in the study area from 2017 to 2019 , determined by inverse-distance weighting, was summed to monthly values and compared to the monthly normal values from 1981 to 2010 at climate site USC00396947. The largest departure from normal was in May 2019 with precipitation exceeding the monthly normal by about 5 inches (in.). All months in 2019, except March, exceeded the monthly normal precipitation. Cumulative departure from normal precipitation in 2019 increased from about 4 in. greater than normal in January to about 18 in. greater than normal in December.

The geologic setting of the study area is characterized by the surrounding Black Hills. Unconsolidated Quaternaryage deposits overlie consolidated to partially consolidated Mesozoic-age and Paleozoic-age shales, sandstones, and limestones. Surficial deposits of alluvium and other unconsolidated deposits are the primary surficial geologic units in the study area and form the components of the alluvium hydrogeologic unit of the study area. Limestone cobbles and boulders detected in the alluvium are similar in texture and color to the limestone outcrops of the Mississippian-age Madison Limestone to the west of the study area. The Triassicto Permian-age Spearfish Formation, exposed at the surface in the study area, is the formation that primarily underlies the Quaternary-age deposits in the Sun Valley Estates subdivision. Paleozoic-age units that underlie the Spearfish Formation include the Permian-age Minnekahta Limestone, Permian-age Opeche Shale, and Permian- to Pennsylvanian-age Minnelusa Formation. These units are exposed at the surface in the higher elevation and steep terrain southwest of the study area.

Hydraulic properties of the alluvial deposits of north Summerset were determined from two sources: (1) estimates of hydraulic properties from previous studies, and (2) aquifer tests at two wells in the study area. The estimates from previous studies were at sites outside the study area but in geologic materials like the alluvial deposits near the study area; therefore, they were considered relevant to the alluvial aquifer material in the study area. Results from previous studies estimated hydraulic conductivity ranging from 89 to $2,292$ feet per day ( $\mathrm{ft} / \mathrm{d})$, transmissivity ranging from 1,001 to 32,083 feet squared per day, and storage coefficients ranging from 0.0002 to 0.16 . Hydraulic conductivity and transmissivity generally decreased downstream along Rapid Creek (west to east). Slug tests were completed August 16, 2019, at two observation wells completed in the alluvial aquifer 
in the Sun Valley Estates subdivision to determine hydraulic conductivity. Hydraulic conductivity estimated from AQTESOLV curve-fitting analysis using the Bouwer-Rice method for all slug-in and slug-out trials from two observation wells in the study ranged from 0.20 to $0.26 \mathrm{ft} / \mathrm{d}$ for well 441318103220001 (SunValley1 well) and from 0.54 to $14 \mathrm{ft} / \mathrm{d}$ for well 441319103215701 (SunValley2 well). The mean, median, and standard deviation of all trials at both wells were $4.3 \mathrm{ft} / \mathrm{d}, 0.8 \mathrm{ft} / \mathrm{d}$, and $5.6 \mathrm{ft} / \mathrm{d}$, respectively.

A simple conceptual model of the groundwater system of the alluvial aquifer in the area of interest near north Summerset, South Dakota, was developed and included aquifer extent and dimensions, the direction of groundwater flow, recharge and evapotranspiration estimates, and an estimated water budget of inflows and outflows of groundwater. The alluvial aquifer extent was determined by geologic maps and lithologic logs, and the extent of the alluvial deposits in the study area are about 1 mile in the north-south direction and about 1.5 miles in the southeast-northwest direction. The groundwater-flow system was estimated using water-level records and topographic maps, and the resulting potentiometric map indicated that groundwater in the alluvial aquifer under the Sun Valley Estates subdivision originates from higher elevations of the west part of the area of interest and from streams in the southeast part. Recharge and evapotranspiration estimates were results from a Soil-Water Balance (SWB) model that calculated a matrix of recharge for 2019 with values ranging from 0 to $11.4 \mathrm{in}$. and an annual mean value of $5.1 \mathrm{in}$. across the study area. Annual SWB-estimated potential evapotranspiration for 2019 ranged from 28.90 to $28.75 \mathrm{in}$. and the estimated annual mean was $28.86 \mathrm{in}$. across the study area. Estimated groundwater budget components for the alluvial aquifer in the area of interest included inflows and outflows. Total estimated groundwater budget components for inflows for 2019 were about 66 percent from recharge, 33 percent from stream discharge, and 1 percent from inflow from adjacent aquifers. Total estimated outflows were about 99-percent evapotranspiration and less than 1-percent outflow to adjacent aquifers.

The data and methods of data interpretation had several limitations that could affect the accuracy of the hydrogeologic characterization of the study area. Limitations included (1) the few sources of data for water levels, lithology, and climate data available in the study area; (2) the interpretive curvefitting methods used for calculating hydraulic conductivity from slug-test data; (3) the assumptions for the SWB model; and (4) the estimates used for budget calculation.

\section{References Cited}

AQTESOLV, 2020, Bouwer and Rice slug test solution for unconfined aquifers: HydroSOLVE, Inc., web page, accessed June 2020 at http://www.aqtesolv.com/bouwerrice.htm.

Bouwer, H., and Rice, R.C., 1976, A slug test for determining hydraulic conductivity of unconfined aquifers with completely or partially penetrating wells: Water Resources Research, v. 12, no. 3, p. 423-428. [Also available at https://doi.org/10.1029/WR012i003p00423.]

Butler, J.J., 1998, The Design, performance, and analysis of slug tests: Boca Raton, Lewis Publishers, 252 p.

Canadell, J., Jackson, R.B., Ehleringer, J.B., Mooney, H.A., Sala, O.E., and Schulze, E.D., 1996, Maximum rooting depth of vegetation types at the global scale: Oecologia, v. 108 , no. 4, p. 583-595. [Also available at https://doi.org/ 10.1007/BF00329030.]

Carter, J.M., Driscoll, D.G., and Hamade, G.R., 2001a, Estimated recharge to the Madison and Minnelusa aquifers in the Black Hills area, South Dakota and Wyoming, water years 1931-98: U.S. Geological Survey Water-Resources Investigations Report 2000-4278, 66 p. [Also available at https://doi.org/10.3133/wri004278.]

Carter, J.M., Driscoll, D.G., Hamade, G.R., and Jarrell, G.J., 2001b, Hydrologic budgets for the Madison and Minnelusa aquifers in the Black Hills of South Dakota and Wyoming, water years 1987-96: U.S. Geological Survey WaterResources Investigations Report 2001-4119, 53 p. [Also available at https://doi.org/10.3133/wri014119.]

Carter, J.M., Driscoll, D.G., Williamson, J.E., and Lindquist, V.A., 2002, Atlas of water resources in the Black Hills area, South Dakota: U.S. Geological Survey Hydrologic Atlas 747, 120 p. [Also available at https://doi.org/ 10.3133/ha747.]

City of Summerset, 2016, Summerset comprehensive plan: City of Summerset, $31 \mathrm{p}$.

Coker, D., 1981, Shallow groundwater resources of a portion of Rapid Valley, Pennington County, South Dakota: Rapid City, South Dakota School of Mines and Technology, master's thesis, $96 \mathrm{p}$.

Cunningham, W.L., and Schalk, C.W., comps., 2011, Groundwater technical procedures of the U.S. Geological Survey: U.S. Geological Survey Techniques and Methods, book 1, chap. A1, 151 p., accessed February 2020 at https://doi.org/10.3133/tm1A1. 
Dickinson, W.R., Klute, M.A., Hayes, M.J., Janecke, S.U., Lundin, E.R., McKittrick, M.A., and Olivares, M.D., 1988, Paleogeographic and paleotectonic setting of Laramide sedimentary basins in the central Rocky Mountain region: Geological Society of America Bulletin, v. 100, no. 7, p. 1023-1039. [Also available at https://doi.org/10.1130/ 0016-7606(1988)100<1023:PAPSOL $>2.3 . C O ; 2$.

Driscoll, D.G., 1994, Black Hills hydrology study: U.S. Geological Survey Open File Report 94-344, 4 p. [Also available at https://doi.org/10.3133/ofr94344.]

Driscoll, D.G., Carter, J.M., Williamson, J.E., and Putnam, L.D., 2002, Hydrology of the Black Hills area, South Dakota: U.S. Geological Survey Water-Resources Investigations Report 02-4094, 150 p. [Also available at https://doi.org/10.3133/wri024094.]

Duffield, G.M., 2020, Recommended normalized head range for slug test analysis: HydroSOLVE, Inc., web page, accessed June 2020 at http://www.aqtesolv.com/slug-tests/ recommended-normalized-head-ranges.htm.

Eldridge, W.G., 2020, Soil-Water Balance model for alluvial deposits in Summerset, South Dakota: U.S. Geological Survey data release, https://doi.org/10.5066/P9TKVMXU.

Esri, 2019, How Topo To Raster works: Esri web page, accessed April 29, 2019, at https://pro.arcgis.com/en/ pro-app/tool-reference/3d-analyst/how-topo-to-rasterworks.htm.

Feldman, R.M., and Heimlich, R.A., 1980, The Black Hills: Kent, Ohio, Kent State University, K/H Geology Field Guide Series, 190 p.

Freeze, R.A., and Cherry, J.A., 1979, Groundwater: Englewood Cliffs, N.J., Prentice-Hall, 604 p.

Hargreaves, G.H., and Samani, Z.A., 1985, Reference crop evapotranspiration from temperature: Applied Engineering in Agriculture, v. 1, no. 2, p. 96-99. [Also available at https://doi.org/10.13031/2013.26773.]

Heath, R.C., 1983, Basic ground-water hydrology: U.S. Geological Survey Water Supply Paper 2220, 86 p. [Also available at https://doi.org/10.3133/wsp2220.]

Hyder, Z., Butler, J.J., Jr., McElwee, C.D., and Liu, W., 1994, Slug tests in partially penetrating wells: Water Resources Research, v. 30, no. 11, p. 2945-2957. [Also available at https://doi.org/10.1029/94WR01670.]

Hydrosolve, Inc., 2007, AQTESOLV for Windows-Version 4.5 user's guide: Reston, Va., 513 p., accessed February 2020 at http://www.aqtesolv.com/download/ aqtw20070719.pdf.
KellerLynn, K., 2009, Jewel Cave National Monument geologic resources inventory report: National Park Service Natural Resources Report NPS/NRPC/GRD/ NRR-2009/084, 46 p.

Koss, W.J., Ownby, J.R., Steurer, P.M., and Ezell, D.S., 1988, Freeze/frost data: National Climatic Data Center Climatography of the U.S. No. 20, Supplement No. $1,206 \mathrm{p}$.

Lisenbee, A.L., and Hargrave, R.G., 2005, Geologic map of the Blackhawk quadrangle, South Dakota: South Dakota Geological Survey, 7.5 Minute Series Geological Quadrangle Map 5. [Also available at http://www.sdgs.usd.edu/pubs/pdf/GQ24K-05 20050629.pdf.]

Martin, J.E., Sawyer, J.F., Fahrenbach, M.D., Tomhave, D.W., and Schulz, L.D., 2004, Geologic map of South Dakota: South Dakota Department of Environment and Natural Resources, General Map 10, scale 1:500,000.

Musa, N.S., 1984, Hydrogeology of the alluvial aquifer in eastern Rapid City, Pennington County, South Dakota: Rapid City, South Dakota School of Mines and Technology, master's thesis, $96 \mathrm{p}$.

National Oceanic and Atmospheric Administration, 2019a, Climate data online: National Oceanic and Atmospheric Administration web page, accessed January 2020 at https:// www.ncdc.noaa.gov/cdo-web.

National Oceanic and Atmospheric Administration, 2019b, Precipitation measurements: National Oceanic and Atmospheric Administration web page, accessed January 2020 at https://www.weather.gov/abrfc/map.

National Oceanic and Atmospheric Administration, 2019c, Climate normal: National Oceanic and Atmospheric Administration web page, accessed January 2020 at https://www. ncdc.noaa.gov/data-access/land-based-station-data/landbased-datasets/climate-normals.

Pandit, N.S., and Miner, R.F., 1986, Interpretation of slug test data: Ground Water, v. 24, no. 6, p. 743-749. [Also available at https://doi.org/10.1111/j.1745-6584.1986.tb01690.x.]

PRISM Climate Group, 2014, Average annual precipitation for South Dakota (1981-2010): Northwest Alliance for Computational Science and Engineering, accessed August 2020 at http://www.prism.oregonstate.edu/projects/gallery_view. php? state $=$ SD.

Redden, J.A., 2018, Geologic map of the Piedmont quadrangle, South Dakota: South Dakota Geological Survey, 7.5 Minute Series Geological Quadrangle Map 10. [Also available at https://doi.org/10.3133/sim2777.] 
Redden, J.A., and DeWitt, E., 2008, Maps showing geology, structure, and geophysics of the central Black Hills, South Dakota: U.S. Geological Survey Scientific Investigations Map 2777, 44-p. pamphlet, 2 sheets. [Also available at https://doi.org/10.3133/sim2777.]

South Dakota Department of Environment and Natural Resources, 2019, Water well completion reports database: South Dakota Department of Energy and Natural Resources digital data, accessed March 15, 2019, at https://apps.sd.gov/nr68welllogs/.

South Dakota Geological Survey, 2018, Lithologic logs database: South Dakota Geological Survey digital data, accessed March 15, 2019, at http://cf.sddenr.net/lithdb/.

South Dakota State University, 2014, Vegetable gardening in South Dakota: Brookings, S. Dak., South Dakota State University iGrow, 18 p., accessed August 24, 2019, at https:// silo.tips/download/vegetable-gardening-in-south-dakota.

Stetler, L.D., 1989, Evaluation of new infiltration gallery sites to augment Rapid City's water supply: Rapid City, South Dakota School of Mines and Technology, master's thesis, $162 \mathrm{p}$.

Taylor, C.J., and Alley, W.M., 2001, Ground-water-level monitoring and the importance of long-term water-level data: U.S. Geological Survey Circular 1217, 68 p. [Also available at https://doi.org/10.3133/cir1217.]

Thornthwaite, C.W., and Mather, J.R., 1957, Instructions and tables for computing potential evapotranspiration and the water balance: Climatology, v. 10, no. 3, 311 p.

Tillman, F.D., 2015, Documentation of input datasets for the soil-water balance groundwater recharge model of the Upper Colorado River Basin: U.S. Geological Survey Open-File Report 2015-1160, 17 p., accessed August 2020 at https://doi.org/10.3133/ofr20151160.

Turnipseed, D.P., and Sauer, V.B., 2010, Discharge measurements at gaging stations: U.S. Geological Survey Techniques and Methods, book 3, chap. A8, 87 p., accessed August 2020 at https://doi.org/10.3133/tm3A8.

U.S. Army Corps of Engineers, 2018, Black Hills Flood Risk Demonstration Project, City of Summerset, Meade County: South Dakota, U.S. Army Corps of Engineers, Omaha District Flood Risk and Floodplain Management Section, $39 \mathrm{p}$.

U.S. Census Bureau, 2018, TIGER/Line Shapefile, 2018, county, Meade County, SD, All Roads County-based Shapefile: U.S. Census Bureau digital data, accessed August 2020 at https://catalog.data.gov/dataset/tiger-line-shapefile2018-county-meade-county-sd-all-roads-county-basedshapefile.
U.S. Department of Agriculture, 2004, Chapter 9-Hydrologic soil-cover complexes: Natural Resources Conservation Service, Part 630, Hydrology National Engineering Handbook, 210-VI-NEH, 20 p., accessed August 2020 at https://directives.sc.egov.usda.gov/OpenNonWebContent. aspx? content=17758.wba.

U.S. Department of Agriculture, 2009, Chapter 7-Hydrologic soil groups: Natural Resources Conservation Service, Part 630, Hydrology National Engineering Handbook, 210-VINEH, 13 p., accessed August 2020 at https://www.wcc.nrcs. usda.gov/ftpref/wntsc/H\&H/NEHhydrology/ch7.pdf.

U.S. Department of Agriculture, 2014, Gridded Soil Survey Geographic (gSSURGO) database user guide, version 1.1: National Soil Survey Center, National Geospatial Center of Excellence, $85 \mathrm{p}$.

U.S. Department of Agriculture, 2018, Geospatial Data Gateway: Natural Resources Conservation Service web page, accessed March 2019 at https://gdg.sc.egov.usda.gov/ GDGOrder.aspx.

U.S. Geological Survey, 2016, The StreamStats program for South Dakota: U.S. Geological Survey web page, accessed June 2020 at http://water.usgs.gov/osw/streamstats/ southdakota.html.

U.S. Geological Survey, 2017, 1 meter Digital Elevation Models (DEMs) - USGS National Map 3DEP downloadable data collection: U.S. Geological Survey digital data, accessed August 2020 at https://catalog.data.gov/dataset/ usgs-national-elevation-dataset-ned-1-meter-downloadabledata-collection-from-the-national-map-.

U.S. Geological Survey, 2019, USGS water data for the Nation: U.S. Geological Survey National Water Information System database, accessed January 2020 at https://doi.org/ 10.5066/F7P55KJN.

U.S. Geological Survey, 2020, Geologic units containing alluvium: U.S. Geological Survey web page, accessed June 2020 at https://mrdata.usgs.gov/geology/state/sgmclith.php?text=alluvium.

Westenbroek, S.M., Kelson, V.A., Dripps, W.R., Hunt, R.J., and Bradbury, K.R., 2010, SWB-A modified Thornthwaite-Mather soil-water-balance code for estimating groundwater recharge: U.S. Geological Survey Techniques and Methods, book 6, chap. A31, 60 p. [Also available at https://doi.org/10.3133/tm6A31.]

Whitehead, R.L., 1996, Ground water atlas of the United States-Segment 8, Montana, North Dakota, South Dakota, Wyoming: U.S. Geological Survey Hydrologic Atlas 730-I, 24 p. [Also available at https://doi.org/10.3133/ha730I.] 
Wilson, W.E., and Moore, J.E., eds., 1998, Glossary of hydrology: Alexandria, Va., American Geological Institute, $248 \mathrm{p}$.

Yang, L., Jin, S., Danielson, P., Homer, C.G., Gass, L., Bender, S.M., Case, A., Costello, C., Dewitz, J.A., Fry, J.A., Funk, M., Granneman, B.J., Liknes, G.C., Rigge, M.B., and Xian, G., 2018, A new generation of the United States National Land Cover Database-Requirements, research priorities, design, and implementation strategies: ISPRS Journal of Photogrammetry and Remote Sensing, v. 146, p. 108-123. [Also available at https://doi.org/10.1016/ j.isprsjprs.2018.09.006.] 

For more information about this publication, contact: Director, USGS Dakota Water Science Center 821 East Interstate Avenue, Bismarck, ND 58503

1608 Mountain View Road, Rapid City, SD 57702

605-394-3200

For additional information, visit: https://www.usgs.gov/centers/dakota-water

Publishing support provided by the Rolla Publishing Service Center 
